\title{
Chemical Constituents Isolated from the Bark of Guatteria blepharophylla (Annonaceae) and their Antiproliferative and Antimicrobial Activities
}

\author{
Emmanoel V. Costa, ${ }^{a, b}$ Francisco de Assis Marques, ${ }^{a}$ Maria Lúcia B. Pinheiro, ${ }^{c}$ \\ Raquel M. Braga, ${ }^{d}$ Camila Delarmelina, ${ }^{e}$ Marta Cristina T. Duarte, ${ }^{e}$ Ana Lúcia T. G. Ruiz, ${ }^{f}$ \\ João Ernesto de Carvalho ${ }^{f}$ and Beatriz H. L. N. S. Maia ${ }^{*, a}$
}

a Departamento de Química, Universidade Federal do Paraná, CP 19081, 81531-990 Curitiba-PR, Brazil

${ }^{b}$ Departamento de Química, Universidade Federal de Sergipe, 49100-000 São Cristovão-SE, Brazil

${ }^{c}$ Departamento de Química, Universidade Federal do Amazonas, 69077-000 Manaus-AM, Brazil

${ }^{d}$ Instituto de Química, Universidade Estadual de Campinas, CP 6154, 13083-970 Campinas-SP, Brazil

${ }^{e}$ Divisão de Microbiologia and ${ }^{f}$ Divisão de Farmacologia e Toxicologia, CPQBA, Universidade Estadual de Campinas, CP 6171, 13083-970 Campinas-SP, Brazil

\begin{abstract}
O estudo fitoquímico das cascas de Guatteria blepharophylla (Mart.) Mart. forneceu 12 compostos, sendo dois sesquiterpenos, óxido de cariofileno (1) e espatulenol (3), uma xantona, liquexantona (2), uma mistura de esteróides, $\beta$-sitosterol (4) e estigmasterol (5), e sete alcalóides isoquinolínicos, $O$-metilmoschatolina (6), lysicamina (7), nornuciferina (8), liriodenina (9), isocoreximina (10), subsessilina (11) e isomoschatolina (12). Suas estruturas foram determinadas através de métodos espectroscópicos. Os compostos 1-6,11 e 12 são reportados pela primeira vez nesta espécie. Os dados de RMN ${ }^{13} \mathrm{C}$ (ressonância magnética nuclear) para os compostos $\mathbf{1 1}$ e $\mathbf{1 2}$ são descritos pela primeira vez na literatura. As atividades antiproliferativa em linhagens de células tumorais humanas e antimicrobiana foram investigadas para os compostos majoritários. O composto 9 mostrou significativa atividade contra linhagens de células de mama (MCF-7, Michigan Cancer Foundation-7), superior ao controle positivo doxorrubicina. O composto $\mathbf{1 2}$ apresentou atividade antifúngica similar ao controle positivo nistatina contra Candida albicans.
\end{abstract}

Phytochemical study of the bark of Guatteria blepharophylla (Mart.) Mart. afforded twelve compounds, namely two sesquiterpenes, caryophyllene oxide (1) and spathulenol (3), one xanthone, lichexanthone (2), a mixture of steroids, $\beta$-sitosterol (4), and stigmasterol (5), and seven isoquinoline alkaloids, $O$-methylmoschatoline (6), lysicamine (7), nornuciferine (8), liriodenine (9), isocoreximine (10), subsessiline (11), and isomoschatoline (12). Their structures were established on the basis of spectroscopic methods. Compounds 1-6, 11 and $\mathbf{1 2}$ were reported for the first time in this species. The ${ }^{13} \mathrm{C}$ NMR (nuclear magnetic resonance) data for the compounds $\mathbf{1 1}$ and $\mathbf{1 2}$ are described for the first time in the literature. The antiproliferative activity against human tumour cell lines and antimicrobial activities were investigated for the major compounds. Compound 9 showed significant activity against cell lines of breast (MCF-7, Michigan Cancer Foundation-7), superior to the positive control doxorubicin. Compound $\mathbf{1 2}$ presented antifungal activity similar to the positive control nystatin against Candida albicans.

Keywords: Guatteria blepharophylla, antifungal and antiproliferative activities, alkaloids, terpenes, xanthone

\section{Introduction}

The genus Guatteria Ruiz \& Pav. contains close to 290 species and is the largest genus within the Annonaceae

*e-mail: noronha@ufpr.br family. ${ }^{1}$ Species of Guatteria are frequent constituents of Neotropical (lowland) forests, and it is widely distributed throughout Mesoamerica, the Caribbean and tropical South America. ${ }^{1}$

Plants of this family are known for their edible fruits and medicinal properties of many species. ${ }^{2}$ Previous chemical 
and pharmacological investigations on some species of this family, including Guatteria, have indicated the presence of important bioactive compounds, exhibiting many pharmacological activities, such as, cytotoxicity against human tumor cell lines, ${ }^{3-5}$ antimicrobial,, $5-9$ and antiparasitic properties, particularly against Leishmania sp., 3,7,10-12 Plasmodium falciparum ${ }^{5,12,13}$ and Trypanosoma sp. ${ }^{3,12,14}$

Despite the importance of annonaceous members in folk medicine, the number of species that have been chemically investigated is still very small. One of them is Guatteria blepharophylla Mart in Mart, a small tropical tree that occurs in the Amazonian region (Brazil, Peru, Guyana, Ecuador and Venezuela). ${ }^{1}$ In Brazil this species is common in Amazonas and Pará states, where it is known as "envireira". ${ }^{15}$ Previous phytochemical studies on this species described the isolation and identification of essential oils and isoquinoline alkaloids. ${ }^{8,15,16}$

In continuation of our research on bioactive compounds from Amazonian annonaceous plants, we report herein the phytochemical study of the bark of G. blepharophylla and the evaluation of antiproliferative and antimicrobial properties of the main isolated compounds.

\section{Experimental}

\section{General experimental procedures}

Melting points were determined on a Quimis Q-340S23 micromelting point apparatus. UV-Vis spectra were obtained in $\mathrm{CH}_{3} \mathrm{OH}$ on a Hewlett-Packard HP 8452A diode array spectrophotometer. IR spectra were acquired on a BIORAD FTS-3500 GX spectrophotometer. Mass spectra were recorded on a Varian Saturn 2000 spectrometer operating at $70 \mathrm{eV}$. NMR data, $1 \mathrm{D}$ and 2D, were recorded at $293 \mathrm{~K}$ in $\mathrm{CDCl}_{3}$ or $\mathrm{CDCl}_{3}+\mathrm{CD}_{3} \mathrm{OD}$ or $\mathrm{CD}_{3} \mathrm{OD}$ on a Bruker Avance DRX 400 and Brucker ARX 200 spectrometers. The spectrometers were equipped with a $5 \mathrm{~mm}$ multinuclear direct detection probe with $z$-gradient. One-bond and longrange ${ }^{1} \mathrm{H}-{ }^{13} \mathrm{C}$ correlation (HSQC, (heteronuclear single quantum correlation) and $\mathrm{HMBC}$ (heteronuclear multiple bond coherence), respectively) experiments were optimized for an average coupling constants ${ }^{1} J_{(\mathrm{C}, \mathrm{H})}$ and ${ }^{\mathrm{LR}} J_{(\mathrm{C}, \mathrm{H})}$ of 140 and $8 \mathrm{~Hz}$, respectively. All ${ }^{1} \mathrm{H}$ and ${ }^{13} \mathrm{C}$ NMR chemical shifts $(\delta)$ are given in ppm related to the TMS (tetramethylsilane) signal at $0.00 \mathrm{ppm}$ as internal reference and the coupling constants $(J)$ in Hz. Silica gel 60 (70-230 mesh) was used for column chromatography, while silica gel $60 \mathrm{~F}_{254}$ were used for analytical $(0.25 \mathrm{~mm})$, and preparative $(1.00 \mathrm{~mm}) \mathrm{TLC}$. Compounds were visualized by exposure under $\mathrm{UV}_{254 / 366}$ light, spraying $p$-anisaldeyde reagent followed by heating on a hot plate, or spraying with Dragendorff's reagent.

\section{Plant material}

The bark of G. blepharophylla was collected in January 2005 on the campus of the Universidade Federal do Amazonas (UFAM), Manaus-AM, Brazil, and identified by the taxonomist Prof. Dr. A. C. Webber from UFAM. A voucher specimen (number 7340) has been deposited at the Herbarium of the UFAM. After identification, G. blepharophylla bark was dried at room temperature and finely powdered.

\section{Extraction and isolation of the chemical constituents}

The dried powdered bark (1500 g) of G. blepharophylla was successively extracted with $n$-hexane followed by $\mathrm{MeOH}$ to yield $n$-hexane (28.18 g) and $\mathrm{MeOH}(212.50 \mathrm{~g}$ ) extracts.

The $n$-hexane extract ( $3.50 \mathrm{~g}$ ) was subjected to silica gel column chromatography eluted with the gradient systems: petroleum ether- $\mathrm{CH}_{2} \mathrm{Cl}_{2}$ from 100:0 to 10:90 (v/v) followed by $\mathrm{CH}_{2} \mathrm{Cl}_{2}$-EtOAc from 100:0 to 10:90 (v/v), and EtOAc-MeOH from 100:0 to 80:20 (v/v), affording 295 fractions (each $15 \mathrm{~mL}$ ). The eluted fractions were evaluated and pooled according to TLC analysis, to afford 24 groups of fractions. Fraction 4 ( $340.7 \mathrm{mg}$ ) was submitted to further silica gel column chromatography eluted with the gradient systems: petroleum ether- $\mathrm{CH}_{2} \mathrm{Cl}_{2}$ from 100:0 to 10:90 (v/v), and $\mathrm{CH}_{2} \mathrm{Cl}_{2}-\mathrm{EtOAc}$ from 100:0 to 10:90 (v/v), yielding 40 subfractions that were pooled in nine subfractions according to TLC analysis. Subfraction $4.4(154.7 \mathrm{mg})$ was purified by preparative TLC eluted with petroleum ether-EtOAc (90:10, v/v, two times) to give $\mathbf{1}(56.7 \mathrm{mg})$ and $\mathbf{2}(20.0 \mathrm{mg})$. Fraction $5(187.2 \mathrm{mg})$ was also submitted to another silica gel column chromatography using the same methodology described for fraction 4 affording 40 new subsfractions that were pooled in nine groups of subfractions, according to TLC analysis. Subfractions $5.3(14.0 \mathrm{mg})$ and 5.4 $(55.7 \mathrm{mg})$ were purified by preparative TLC eluted with petroleum ether-EtOAc $(90: 10, \mathrm{v} / \mathrm{v}$, two times) to give $\mathbf{2}$ $(3.0 \mathrm{mg})$, and $\mathbf{3}(16.8 \mathrm{mg})$, respectively. Fraction 6 were also submitted to silica gel column chromatography using the same methodology above yielding 56 subfractions that were pooled in ten groups of subfractions, according to TLC analysis. Subfraction 6.6 was purified by preparative TLC eluted with petroleum ether-EtOAc (80:20, v/v, two times) to yield a mixture of $\mathbf{4}$ and $\mathbf{5}(36.1 \mathrm{mg})$.

TLC investigations indicated a high concentration of alkaloids in the $\mathrm{MeOH}$ extract. Therefore, an aliquot of the $\mathrm{MeOH}$ extract $(210.0 \mathrm{~g})$ was initially subjected to an acid-base extraction ${ }^{10}$ to give the $\mathrm{CH}_{2} \mathrm{Cl}_{2}$ alkaloid fraction $(1.18 \mathrm{~g})$ and the $\mathrm{CH}_{2} \mathrm{Cl}_{2}$ neutral fraction $(5.24 \mathrm{~g})$. The 
alkaloid fraction $(1.0 \mathrm{~g})$ was subjected to $10 \% \mathrm{NaHCO}_{3}$ treated silica gel column chromatography ${ }^{10}$ eluted with the gradient systems: petroleum ether- $\mathrm{CH}_{2} \mathrm{Cl}_{2}$ from 100:0 to 10:90 (v/v) followed by $\mathrm{CH}_{2} \mathrm{Cl}_{2}-\mathrm{EtOAc}$ from 100:0 to 10:90 (v/v), and EtOAc-MeOH from 100:0 to 50:50 (v/v), yielding 97 fractions (each $25 \mathrm{~mL}$ ). The eluted fractions were evaluated and pooled according to TLC analysis, to afford 13 groups of fractions. Fraction $4(112.8 \mathrm{mg})$ was purified by preparative TLC eluted with $\mathrm{CH}_{2} \mathrm{Cl}_{2}-\mathrm{MeOH}$ (95:05, v/v, two times) to give $6(13.0 \mathrm{mg}), 7(7.0 \mathrm{mg})$, and $8(8.0 \mathrm{mg})$. Fraction $5(87.0 \mathrm{mg})$ was also purified by preparative TLC eluted with $\mathrm{CH}_{2} \mathrm{Cl}_{2}-\mathrm{MeOH}(95: 05$, v/v, two times) to yield $\mathbf{7}(12.6 \mathrm{mg}), \mathbf{8}(2.8 \mathrm{mg})$ and $\mathbf{9}(2.0 \mathrm{mg})$. Fraction $6(282.3 \mathrm{mg})$ was also submitted to another silica gel column chromatography using the same methodology above affording 27 new subsfractions that were pooled in six groups of subfractions, according to TLC analysis. Subfraction $6.3(101.5 \mathrm{mg})$ was purified by preparative TLC eluted with $\mathrm{CH}_{2} \mathrm{Cl}_{2}-\mathrm{MeOH}$ (90:10, v/v, two times) to give $10(9.0 \mathrm{mg})$. Fraction 8 was purified by preparative TLC eluted with $\mathrm{CH}_{2} \mathrm{Cl}_{2}-\mathrm{MeOH}$ (95:05, v/v, three times) to give $\mathbf{1 1}(12.7 \mathrm{mg})$. Fraction 10 was also purified by preparative TLC eluted with $\mathrm{CH}_{2} \mathrm{Cl}_{2}-\mathrm{MeOH}$ (90:10, v/v, three times) to give $\mathbf{1 2}(31.2 \mathrm{mg})$.

\section{Subsessiline (11)}

Orange needles $\left(\mathrm{CHCl}_{3}: \mathrm{MeOH} 2: 1\right) ; \mathrm{UV} \lambda_{\max } / \mathrm{nm}$ (MeOH) (log ع) 204 (3.89), 238 (3.41), 278 (3.54), 472 (2.95); IR $v_{\max } / \mathrm{cm}^{-1}$ (KBr) 3431, 3132, 3097, 2955, 2934, 2855, 1646, 1602, 1582, 1543, 1492, 1466, 1394, 1380, 1326, 1258, 1206, 1087, 1055, 1015, 994, 872; ${ }^{1} \mathrm{H}$ and ${ }^{13} \mathrm{C}$ NMR data: Table 2.

\section{Isomoschatoline (12)}

Blue needles $\left(\mathrm{CHCl}_{3}: \mathrm{MeOH} 2: 1\right) ; \mathrm{UV} \lambda_{\max } / \mathrm{nm}(\mathrm{MeOH})$ (log ع) 204 (4.23), 238 (3.84), 282 (4.01), 304 (3.93), 468 (3.15), 595 (3.09); IR $v_{\max } / \mathrm{cm}^{-1}$ (KBr) 3325, 2938, 2843, 1660, 1614, 1596, 1578, 1541, 1494, 1410, 1367, 1337, 1300, 1266, 1202, 1042, 996, 801, 691; ${ }^{1} \mathrm{H}$ and ${ }^{13} \mathrm{C}$ NMR data: Table 2.

\section{In vitro anticancer activity assay}

Human tumour cell lines UACC-62 (melanoma), MCF7 (breast), NCI-H460 (lung, non-small cells), OVCAR-03 (ovarian), PC-3 (prostate), HT-29 (colon), 786-0 (renal), K562 (leukemia) and NCI-ADR/RES (ovarian expressing phenotype multiple drugs resistance) were kindly provided by National Cancer Institute (NCI). Stock cultures were grown in medium containing $5 \mathrm{~mL}$ RPMI 1640 $\left(\mathrm{GIBCO}^{\circledR} \mathrm{BRL}\right.$ ) supplemented with $5 \%$ fetal bovine serum.
Penicillin:streptomycin $\left(1000 \mu \mathrm{g} \mathrm{mL}^{-1}: 1000 \mathrm{UI} \mathrm{mL}^{-1}\right.$, $1 \mathrm{~mL} \mathrm{~L}^{-1}$ ) was added to experimental cultures. Cells in 96 well plates (100 $\mu \mathrm{L}$ cells well-1) were exposed to sample concentrations in DMSO/RPMI $(0.25,2.5,25$ and $250 \mu \mathrm{g} \mathrm{mL}^{-1}$ ) (DMSO, dimethyl sulfoxide) at $37^{\circ} \mathrm{C}$, $5 \%$ of $\mathrm{CO}_{2}$ in air for $48 \mathrm{~h}$. Final DMSO concentration did not affect cell viability. Afterwards, cells were fixed with $50 \%$ trichloroacetic acid and cell proliferation determined by spectrophotometric quantification $(540 \mathrm{~nm})$ of cellular protein content using sulforhodamine B assay. Using the concentration-response curve for each cell line, TGI (concentration that produces total growth inhibition or cytostatic effect) ${ }^{17}$ was determined through non-linear regression analysis (Table 1) using software ORIGIN 7.5 (OriginLab Corporation).

\section{In vitro antimicrobial activity}

The growth inhibitory activity of the crude extracts, fractions and isolated compounds was tested against 11 microorganisms (Bacillus subtilis ATCC 5061, Candida albicans ATCC 10231, Enterococcus faecium CCT 5079, Enterococcus hirae ATCC 10541, Escherichia coli ATCC 11775, Micrococcus luteus ATCC 4698, Pseudomonas aeruginosa ATCC 13388, Rhodococcus equi ATCC 6939, Salmonella choleraesuis ATCC 10708, Staphylococcus aureus ATCC 6538 and Staphylococcus epidermidis ATCC 12228).

The bacteria strains were cultured overnight at $36{ }^{\circ} \mathrm{C}$ in Nutrient Agar (Merck), while C. albicans was cultured in Saboraud Dextrose Agar. Inoculum for the assays was prepared by diluting a scraped cell mass in $0.85 \% \mathrm{NaCl}$ solution, adjusted to McFarland scale 0.5 and confirmed by spectrophotometer reading at $580 \mathrm{~nm}$. Cell suspensions were finally diluted to $10^{4} \mathrm{CFU} \mathrm{mL}^{-1}$ for using in the activity assays. MIC (minimal inhibitory concentration) tests were carried out according to Eloff, ${ }^{18}$ using Müller-Hinton broth on a tissue-culture test plate ( 96 wells). The stock solution crude extracts, fractions and isolated compounds were diluted and transferred into the first well, and serial dilutions were made so that concentrations in the range of 1.0-0.015 mg mL-1 were obtained. Chloramphenicol and nystatin (Merck) were used as the reference antibiotic control in the range of $0.25-0.002 \mathrm{mg} \mathrm{mL}^{-1}$. The inoculum was added to all wells, and the plates were incubated at $36^{\circ} \mathrm{C}$ for $48 \mathrm{~h}$. Each concentration was screened in triplicate. Antimicrobial activity was detected by adding $20 \mu \mathrm{L}$ of $0.5 \%$ TTC (triphenyl tetrazolium chloride, Merck) aqueous solution. MIC was defined as the lowest concentration of the sample that inhibited visible growth, as indicated by TCC staining (dead cells are not stained by TTC). 
Table 1. Antiproliferative activity of extracts, fractions and major compounds against cancer cell lines

\begin{tabular}{|c|c|c|c|c|c|c|c|c|c|}
\hline \multirow{3}{*}{ Extracts and fractions } & \multicolumn{9}{|c|}{ TGI $\left(\mu \mathrm{g} \mathrm{mL}^{-1}\right)$} \\
\hline & \multicolumn{9}{|c|}{ Tumor cell lines } \\
\hline & UACC-62 & MCF-7 & NCI-H460 & OVCAR-03 & PC-3 & HT-29 & $786-0$ & K562 & NCI-ADR/RES \\
\hline Hexane & 21.37 & 28.16 & 9.05 & 16.96 & 34.32 & 39.20 & 16.18 & 7.23 & 16.18 \\
\hline $\mathrm{MeOH}$ & 229.46 & 152.25 & 179.35 & 221.16 & 169.99 & 129.73 & 39.27 & 71.43 & $>250$ \\
\hline Alkaloid fraction & 92.53 & 51.53 & $>250$ & 208.77 & 244.53 & 185.62 & 169.56 & NT & 136.60 \\
\hline Neutral fraction & $>250$ & $>250$ & $>250$ & $>250$ & $>250$ & $>250$ & $>250$ & $>250$ & $>250$ \\
\hline Compounds & \multicolumn{9}{|c|}{ TGI $\left(\mu \mathrm{mol} \mathrm{L}{ }^{-1}\right)$} \\
\hline 1 & 260.45 & 282.54 & 305.90 & 333.63 & 290.27 & 293.22 & 330.13 & NT & 347.50 \\
\hline 2 & 275.07 & 274.12 & 554.96 & $>874.12$ & $>874.12$ & 643.28 & 271.85 & NT & 295.31 \\
\hline 6 & NT & $>778.82$ & $>778.82$ & NT & $>778.82$ & $>778.82$ & $>778.82$ & NT & $>778.82$ \\
\hline 7 & NT & 289.38 & 49.52 & NT & $>859.11$ & 228.93 & $>859.11$ & 380.62 & 528.18 \\
\hline 8 & NT & 215.58 & 201.99 & NT & 542.38 & 191.38 & 615.23 & 153.88 & 255.37 \\
\hline 9 & 63.02 & 37.67 & 87.41 & 372.18 & $>909.09$ & $>909.09$ & $>909.09$ & NT & $>909.09$ \\
\hline 10 & $>764.52$ & $>764.52$ & $>764.52$ & $>764.52$ & $>764.52$ & $>764.52$ & $>764.52$ & NT & 131.50 \\
\hline 11 & NT & $>741.84$ & 511.39 & NT & $>741.84$ & $>741.84$ & $>741.84$ & 135.70 & $>741.84$ \\
\hline 12 & 84.53 & 73.97 & 186.74 & 89.87 & 351.79 & 242.02 & 547.72 & NT & 348.47 \\
\hline Doxorubicin $^{a}$ & 0.48 & 46.04 & 14.27 & 10.92 & 5.06 & $>46.04$ & 4.77 & 1.66 & 14.80 \\
\hline
\end{tabular}

${ }^{a}$ Positive control; NT (Not tested); UACC-62 (melanoma), MCF-7 (breast), NCI-H460 (lung, non-small cells), OVCAR-03 (ovarian), PC-3 (prostate), HT-29 (colon), 786-0 (renal), K562 (leukemia), and NCI-ADR/RES (ovarian expressing phenotype multiple drugs resistance); TGI (Total Growth Inhibition).

\section{Results and Discussion}

Once $n$-hexane and $\mathrm{MeOH}$ crude extracts were found to have antiproliferative activity (Table 1), these extracts were subjected to successive chromatographic fractionations as described in the Experimental section leading to the isolation of the chemical constituents 1-12 (Figure 1).

Compounds 1-10 were identified by comparison of their spectroscopic data with those reported in the literature as caryophyllene oxide ${ }^{19}(\mathbf{1})$, lichexanthone ${ }^{20}(\mathbf{2})$, spathulenol ${ }^{19}$ (3), a mixture of $\beta$-sitosterol ${ }^{21}(\mathbf{4})$, and stigmasterol ${ }^{21}$
(5), $O$-methylmoschatoline $e^{22,23}(6)$, lysicamine ${ }^{22,23}$ (7), nornuciferine ${ }^{22}(\mathbf{8})$, liriodenine $\mathrm{e}^{6,23}(\mathbf{9})$, and isocoreximine $\mathrm{e}^{15}$ (10). Compounds 7-10 were recently found on the stem of this species, ${ }^{15}$ while compounds 1-6, 11 and $\mathbf{1 2}$ were reported for the first time in this specie. Compound $\mathbf{2}$ is related for the first time in the genus Guatteria, and it is the second report in the Annonaceae, previously isolated from the roots of Rollinia leptopetala. ${ }^{24}$

Compound 11 was obtained as an orange amorphous powder which was positive to the Dragendorff's test. Its UV-vis spectrum showed absorption peaks at 204, 238,
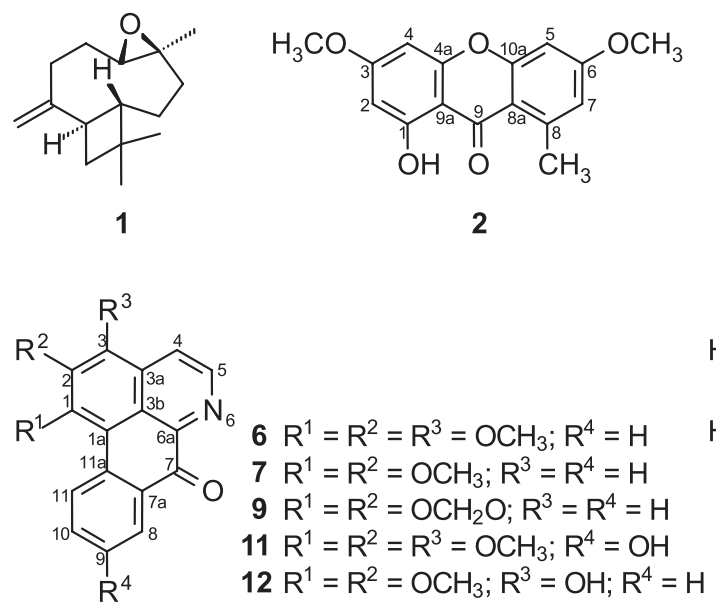

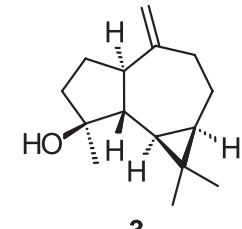

3<smiles>COc1cc2c3c(c1OC)-c1ccccc1CC3NCC2</smiles><smiles>COc1cc2c(cc1O)CC1c3cc(OC)c(O)cc3CCN1C2</smiles>

Figure 1. Chemical constituents isolated from the bark of Guatteria blepharophylla. 
278 and $472 \mathrm{~nm}$, which are typical of molecules with an oxoaporphine skeleton. The IR spectrum showed absorption bands at 3431 and $1646 \mathrm{~cm}^{-1}$, characteristic of phenolic hydroxyl and carbonyl groups. The ${ }^{1} \mathrm{H}$ NMR spectrum indicated a tetrasubstituted-oxoaporphine alkaloid. Its ${ }^{1} \mathrm{H}$ NMR spectrum revealed the presence of a pair of doublets at $\delta 8.88$ and $\delta 8.24$ ( $\mathrm{H}-5$ and $\mathrm{H}-4, J 4.7 \mathrm{~Hz}$, respectively), which was consistent with the presence of a pyridine system. Additionally, it was found to have a spin system consisting of three hydrogens with the signals at $\delta 8.96(1 \mathrm{H}, \mathrm{d}, J 9.0 \mathrm{~Hz}), \delta 7.82(1 \mathrm{H}, \mathrm{d}, J 2.8 \mathrm{~Hz})$, and $\delta 7.25$ $(1 \mathrm{H}, \mathrm{dd}, J 9.0$ and $2.8 \mathrm{~Hz})$, which were attributed to $\mathrm{H}-11$, $\mathrm{H}-8$, and $\mathrm{H}-10$, respectively, and indicated substitution in the D ring. The signals at $\delta 4.05, \delta 4.11$ and $\delta 4.17$ (each $3 \mathrm{H}, s$ ) were assigned to three methoxyl groups located in the A ring, according to long-range ${ }^{1} \mathrm{H}-{ }^{13} \mathrm{C}$ correlation in the HMBC NMR experiment (Table 2). The presence of a hydroxyl group in the molecule located in the $\mathrm{D}$ ring at C-9 was established on the basis of the long-range ${ }^{1} \mathrm{H}-{ }^{13} \mathrm{C}$ correlation of the hydrogen $\mathrm{H}-11$ at $\delta 8.96$ with the carbon C-9 at $\delta$ 157.3, which showed no correlation with the methoxyl groups.

The ${ }^{13} \mathrm{C}$ NMR experiment along with HSQC and HMBC experiments allowed to verify the presence of 19 carbons, including a carbonyl group at $\delta 183.1,15$ aromatic carbons between $\delta$ 157.3-113.4, and three methoxyl groups at $\delta 61.9, \delta 61.4$, and $\delta 60.9$, which was in agreement with structure 11 (Table 2). The hydrogen H-8 at $\delta 7.82$ showed strong long-range ${ }^{1} \mathrm{H}^{13} \mathrm{C}$ correlation with the carbon $\mathrm{C}-7$ at $\delta$ 183.1, which confirmed the oxoaporphine skeleton. According with ${ }^{1} \mathrm{H}$ and ${ }^{13} \mathrm{C}$ NMR 1D/2D this compound was identified as the oxoaporphine alkaloid known subsessiline. This compound has been found only in two species of Annonaceae Guatteria ouregou ${ }^{25}$ and G. subsessilis, ${ }^{26}$ but the physical data are incomplete. The ${ }^{13} \mathrm{C}$ NMR data are reported for the first time. The complete physical data for this compound are described in this work.

Compound $\mathbf{1 2}$ was obtained as a blue amorphous powder. Its UV-Vis spectrum showed absorption peaks at 204, 238, 282, 304, 468 and $595 \mathrm{~nm}$, which are typical of molecules with an oxoaporphine skeleton. The IR spectrum showed absorption bands at 3325 and $1660 \mathrm{~cm}^{-1}$, characteristic of phenolic hydroxyl and carbonyl groups. The ${ }^{1} \mathrm{H}$ and ${ }^{13} \mathrm{C}$ NMR spectra of $\mathbf{1 2}$ were very similar to those of 11, except for the absence of a methoxyl signal, which was replaced by a hydroxyl group, and absence of substitution in the D ring, in structure $\mathbf{1 2}$ according to the IR spectrum and NMR data (Table 2). The absence of

Table 2. NMR spectroscopy data (400 MHz) for compounds $\mathbf{1 1}$ and $\mathbf{1 2}$

\begin{tabular}{|c|c|c|c|c|}
\hline \multirow[t]{2}{*}{ Position } & \multicolumn{2}{|l|}{11} & \multicolumn{2}{|l|}{12} \\
\hline & $\delta_{C}^{a, c}$ & $\delta_{\mathrm{H}}$ mult. $(J \text { in Hz })^{a, c}$ & $\delta_{\mathrm{C}}^{b, c}$ & $\delta_{\mathrm{H}}$ mult. $(J \text { in Hz })^{b, c}$ \\
\hline 1 & 155.5 & & 162.7 & \\
\hline 1a & 116.2 & & 102.7 & \\
\hline 2 & 147.9 & & 144.0 & \\
\hline 3 & 147.5 & & 166.0 & \\
\hline $3 \mathrm{a}$ & 131.4 & & 136.1 & \\
\hline $3 b$ & 122.2 & & 124.7 & \\
\hline 4 & 119.8 & $8.24 \mathrm{~d}(4.7)$ & 124.0 & $8.60 \mathrm{~d}(5.1)$ \\
\hline 5 & 144.0 & $8.88 \mathrm{~d}(4.7)$ & 141.9 & $8.73 \mathrm{~d}(5.1)$ \\
\hline 6a & 145.1 & & 145.0 & \\
\hline 7 & 183.1 & & 184.5 & \\
\hline $7 \mathrm{a}$ & 132.6 & & 130.6 & \\
\hline 8 & 113.4 & $7.82 \mathrm{~d}(2.8)$ & 128.8 & $8.41 \mathrm{ddd}(8.0,1.6$ and 0.5$)$ \\
\hline 9 & 157.3 & & 125.5 & $7.33 \mathrm{ddd}(8.0,7.0$ and 1.0$)$ \\
\hline 10 & 123.2 & $7.25 \mathrm{dd}(9.0$ and 2.8$)$ & 135.1 & $7.68 \mathrm{ddd}(8.6,7.0$ and 1.6$)$ \\
\hline 11 & 129.9 & $8.96 \mathrm{~d}(9.0)$ & 127.3 & $9.08 \mathrm{ddd}(8.6,1.0$ and 0.5$)$ \\
\hline 11a & 126.8 & & 138.7 & \\
\hline $1-\mathrm{OCH}_{3}$ & 60.9 & $4.05 \mathrm{~s}$ & 61.2 & $4.08 \mathrm{~s}$ \\
\hline $2-\mathrm{OCH}_{3}$ & 61.9 & $4.11 \mathrm{~s}$ & 60.6 & $3.97 \mathrm{~s}$ \\
\hline $3-\mathrm{OCH}_{3}$ & 61.4 & $4.17 \mathrm{~s}$ & & \\
\hline
\end{tabular}

The experiments were obtained at $293 \mathrm{~K}$ and TMS as internal reference $(0.00 \mathrm{ppm})$ in ${ }^{\mathrm{a}} \mathrm{CDCl}_{3}+\operatorname{drops}$ of $\mathrm{CD}_{3} \mathrm{OD}$ or ${ }^{\mathrm{b}} \mathrm{CD}_{3} \mathrm{OD} .{ }^{\mathrm{c}}$ Long-range ${ }^{1} \mathrm{H}-{ }^{13} \mathrm{C}$ HMBC correlations, optimized for $8 \mathrm{~Hz}$, is from hydrogens stated for the indicated carbon. 
substitution in the D ring was confirmed by the presence of four adjacent aromatic hydrogens at $\delta 9.08(1 \mathrm{H}$, ddd, $J 8.6$, 1.0 and $0.5 \mathrm{~Hz}), \delta 8.41(1 \mathrm{H}$, ddd, $J 8.0,1.6$ and $0.5 \mathrm{~Hz})$, $\delta 7.68(1 \mathrm{H}$, ddd, $J 8.6,7.0$ and $1.6 \mathrm{~Hz})$, and $\delta 7.33(1 \mathrm{H}$, ddd, $J 8.0,7,0$ and $1.0 \mathrm{~Hz}$ ) which were attributed to $\mathrm{H}-11$, $\mathrm{H}-8, \mathrm{H}-10$, and $\mathrm{H}-9$, respectively (Table 2). The position of the hydroxyl group at $\mathrm{C}-3$ was established on the basis of the long-range ${ }^{1} \mathrm{H}-{ }^{13} \mathrm{C}$ correlation of the hydrogen $\mathrm{H}-4$ at $\delta 8.60$ with the carbon $\mathrm{C}-3$ at $\delta 166.0$, which showed no correlation with the methoxyl groups. According with ${ }^{1} \mathrm{H}$ and ${ }^{13} \mathrm{C}$ NMR $1 \mathrm{D} / 2 \mathrm{D}$, this compound was identified as the oxoaporphine alkaloid known isomoschatoline. As well as observed for 11, the physical data published for this compound are incomplete and presented in this work. The ${ }^{13} \mathrm{C}$ NMR data is reported for the first time. This compound has been found only in three species of Annonaceae Uvaria mocoli, ${ }^{27}$ Guatteria melosma and Cleistopholis patens. ${ }^{28}$

The isolated compounds 1-2 and 6-12 were evaluated for in vitro antiproliferative activity against nine human tumour cell lines (Table 1), while compounds 6, 7,10 and 12 were also tested for antimicrobial activity. Compound $\mathbf{9}$ showed the higher antiproliferative activity for breast (MCF-7) with a TGI value of $37.67 \mu \mathrm{mol} \mathrm{L} \mathrm{L}^{-1}$, more active than positive control doxorubicin (TGI value of $46.04 \mu \mathrm{mol} \mathrm{L}^{-1}$ ). Compound 7 presented significant antiproliferative activity for lung, non-small cells (NCI-H460) with a TGI value of $49.52 \mu \mathrm{mol} \mathrm{L}^{-1}$ (doxorubicin, TGI value of $14.27 \mu \mathrm{mol} \mathrm{L}^{-1}$ ), while compound 12 showed significant activity for breast (MCF-7) with TGI value of $73.97 \mu \mathrm{mol} \mathrm{L}^{-1}$. Compound 10 showed selective activity for ovarian expressing phenotype for multiple drug resistance (NCI-ADR/RES) with a TGI value of $131.50 \mu \mathrm{mol} \mathrm{L}^{-1}$, but was less active than doxorubicin (TGI value of $14.80 \mu \mathrm{mol} \mathrm{L}^{-1}$ (Table 1). Compounds $\mathbf{9}$ and $\mathbf{1 2}$ also showed significant antiproliferative activity against different tumor cell lines with TGI values below to $100 \mu \mathrm{mol} \mathrm{L}^{-1}$ (Table 1).

It is important to notice that compounds $\mathbf{6 , 7 , 9 ,} 11$ and $\mathbf{1 2}$ shared the same basic skeleton with different substitution patterns. This way, our results suggested that a methoxylated substitute at $R_{3}$ reduces antiproliferative activity (compound 11) or even results in an inactive compounds as $\mathbf{6}$, but a hydroxyl group at $\mathrm{R}_{3}$ favored the activity (compound 12). The best results were obtained for methylenedioxy group (compound $\mathbf{9}$ ) or methoxy groups (compounds $\mathbf{7}$ and $\mathbf{1 2}$ ) at $\mathrm{R}_{1}$ and $\mathrm{R}_{2}$.

No significant antibacterial activity was observed for the tested compounds. The only significant antimicrobial result was observed for compound $\mathbf{1 2}$ that showed antifungal activity against $C$. albicans (MIC value of $50.81 \mu \mathrm{mol} \mathrm{L}^{-1}$ ) similar to the positive control nystatin (MIC value of $\left.54.00 \mu \mathrm{mol} \mathrm{L}^{-1}\right)$.

\section{Conclusion}

The chemical investigation of the bark of G. blepharophylla has resulted in the isolation of several compounds common in the taxon Guatteria, such as, $\mathbf{1}$, 3, 6, 7 and 9 that could be considered chemotaxonomic markers of this genus. Compounds 1-6, 11 and $\mathbf{1 2}$ are being reported for the first time in this species, and are important for the chemotaxonomy of Annonaceae family. The significant in vitro antiproliferative results obtained against several human tumour cell lines and antimicrobial activities demonstrated by the major compounds indicate that this species is a natural source of biologically active compounds. Compound $\mathbf{1 2}$ showed significant antifungal and antiproliferative activities against $C$. albicans and human tumor cell lines of breast (MCF-7). Therefore, studies involving mechanisms of action are necessary to fully understand its biological significance.

\section{Supplementary Information}

Supplementary data including physical data for compounds 1-10 and ${ }^{1} \mathrm{H},{ }^{13} \mathrm{C}$ NMR, HSQC and HMBC for compounds $\mathbf{1 1}$ and $\mathbf{1 2}$ are available free of charge at http://jbcs.sbq.org.br as a PDF file.

\section{Acknowledgements}

The authors are grateful to Prof. Dr. A. C. Webber of the Universidade Federal do Amazonas (UFAM) for the botanical identification, as well as, to CAPES, CNPq and Fundação Araucária for financial support.

\section{References}

1. Erkens, R. H. J.; Maas, P. J. M.; Rodriguésia 2008, 59, 401.

2. Corrêa, M. P.; Dicionário das Plantas Úteis do Brasil e das Exóticas Cultivadas, IBDF: Rio de Janeiro, Brasil, 1984.

3. Silva, D. B.; Tulli, E. C. O.; Militão, G. C. G.; Costa-Lotufo, L. V.; Pessoa, C.; Moraes, M. O.; Albuquerque, S.; Siqueira, J. M.; Phytomedicine 2009, 16, 1059.

4. Hsieh, T.-J.; Chang, F.-R.; Chia, Y.-C.; Chen, C.-Y.; Chiu, H.-F.; Wu, Y.-C.; J. Nat. Prod. 2001, 64, 616.

5. Muhammad, I.; Dunbar, D. C.; Takamatsu, S.; Walker, L. A.; Clark, A. M.; J. Nat. Prod. 2001, 64, 559.

6. Costa, E. V.; Marques, F. A.; Pinheiro, M. L. B.; Vaz, N. P.; Duarte, M. C. T.; Delarmelina, C.; Braga, R. M.; Maia, B. H. L. N. S.; J. Nat. Prod. 2009a, 72, 1516.

7. Costa, E. V.; Pinheiro, M. L. B.; Silva, J. R. A.; Maia, B. H. L. N. S.; Duarte, M. C. T.; Amaral, A. C. F.; Machado, G. M. C.; Leon, L. L.; Quim. Nova 2009b, 32, 78. 
8. Costa, E. V.; Teixeira, S. D.; Marques, F. A.; Duarte, M. C. T.; Delarmelina, C.; Pinheiro, M. L. B.; Trigo, J. R.; Maia, B. H. L. N. S.; Phytochemistry 2008, 69, 1895.

9. Costa, E. V.; Pinheiro, M. L. B.; Barison, A.; Campos, F. R.; Salvador, M. J.; Maia, B. H. L. N. S.; Cabral, E. C.; Eberlin, M. N.; J. Nat. Prod. 2010, 73, 1180.

10. Costa, E. V.; Pinheiro, M. L. B.; Xavier, C. M.; Silva, J. R. A.; Amaral, A. C. F.; Souza, A. D. L.; Barison, A.; Campos, F. R.; Ferreira, A. G.; Machado, G. M. C.; Leon, L. L. P. J.; J. Nat. Prod. 2006, 69, 292.

11. Montenegro, H.; Gutiérrez, M.; Romero, L. I.; Ortega-Barría, E.; Capson, T. L.; Rios, L.C.; Planta Med. 2003, 69, 677.

12. Mahiou, V.; Roblot, F.; Fournet, A.; Hocquemiller, R.; Phytochemistry 2000, 54, 709.

13. Boyom, F. F.; Ngouana, V.; Zollo, P. H. A.; Menut, C.; Bessiere, J. M.; Gut, J.; Rosenthal, P. J.; Phytochemistry 2003, 64, 1269.

14. Waechter, A.-I.; Cavé, A.; Hocquemiller; R.; Bories, C.; Muñoz, V.; Fournet, A.; Phytother. Res. 1999, 13, 175.

15. Costa, E. V.; Pinheiro, M. L. B.; Marques, F. A.; Braga, R. M.; Maia, B. H. L. N. S.; Biochem. Syst. Ecol. 2009c, 37, 43.

16. Maia, J. G. S.; Andrade, E. H. A.; Carreira, L. M. M.; Oliveira, J.; Araújo, J. S.; Flavour Frag. J. 2005, 20, 478.

17. Shoemaker, R. H.; Nat. Rev. Cancer 2006, 6, 813.

18. Ellof, J. N.; Planta Med. 1998, 64, 711.

19. Ragasa, C. Y.; Ganzon, J.; Hofileña, J.; Tamboong, B.; Rideout, J. A.; Chem. Pharm. Bull. 2003, 51, 1208.
20. Micheletti, A. C.; Beatriz, A.; Lima, D. P.; Honda, N. K.; Pessoa, C. O.; Moraes, M. O.; Lotufo, L. V.; Magalhães, H. I. F.; Carvalho, N. C. P.; Quim. Nova 2009, 32, 12.

21. Facundo, V. A.; Polli, A. R.; Rodrigues, R. V.; Militão, J. S. L. T.; Stabelli, R. G.; Cardoso, C. T.; Acta Amaz. 2008, 38, 733.

22. Guinaudeau, H.; Leboeuf, M.; Cavé, A.; J. Nat. Prod. 1983, 46, 761.

23. Harrigan, G. G.; Gunatilaka, A. A. L.; Kingston, D. G. I.; Chan, G. W.; Johnson, R. K.; J. Nat. Prod. 1994, 57, 68.

24. Arriaga, A. M. C.; Feitosa, E. M. A.; Lemos, T. L. G.; Santiago, G. M. P.; Lima, J. Q.; De Oliveira, M. C. F.; Vasconcelos, J. N. E.; Rodrigues, F. E. A.; Gomes, T. B. M.; Braz-Filho, R.; Nat. Prod. Commun. 2008, 3, 1687.

25. Cortes, D.; Hocquemiller, R.; Leboeuf, M.; Cavé, A.; Morreti, C.; J. Nat. Prod. 1986, 49, 878.

26. Hasegawa, M.; Sojo, M.; Lira, A.; Marques, C.; Acta Cient. Venez. 1972, 23, 165.

27. Fleischer, T. C.; Waigh, R. D.; Waterman, P. G.; Phytochemistry 1998, 47, 1387.

28. Atti, S. A.-E.; Ammar, H. A.; Phoebe Jr., C.H.; Schiff Jr., P. L.; Slatkin, D. J.; J. Nat. Prod. 1982, 45, 476.

Submitted: July 14, 2010

Published online: February 17, 2011

FAPESP has sponsored the publication of this article. 


\title{
Chemical Constituents Isolated from the Bark of Guatteria blepharophylla (Annonaceae) and their Antiproliferative and Antimicrobial Activities
}

\author{
Emmanoel V. Costa, ${ }^{a, b}$ Francisco de Assis Marques, ${ }^{a}$ Maria Lúcia B. Pinheiro, ${ }^{c}$ \\ Raquel M. Braga, ${ }^{d}$ Camila Delarmelina, ${ }^{e}$ Marta Cristina T. Duarte, ${ }^{e}$ Ana Lúcia T. G. Ruiz, ${ }^{f}$ \\ João Ernesto de Carvalho ${ }^{f}$ and Beatriz H. L. N. S. Maia ${ }^{*, a}$ \\ a Departamento de Química, Universidade Federal do Paraná, CP 19081, 81531-990 Curitiba-PR, Brazil \\ ${ }^{b}$ Departamento de Química, Universidade Federal de Sergipe, 49100-000 São Cristovão-SE, Brazil \\ 'Departamento de Química, Universidade Federal do Amazonas, 69077-000 Manaus-AM, Brazil \\ ${ }^{d}$ Instituto de Química, Universidade Estadual de Campinas, CP 6154, 13083-970 Campinas-SP, Brazil \\ ${ }^{e}$ Divisão de Microbiologia and ${ }^{f}$ Divisão de Farmacologia e Toxicologia, CPQBA, Universidade \\ Estadual de Campinas, CP 6171, 13083-970 Campinas-SP, Brazil
}

Table S1. Chemical constituents isolated from the bark of Guatteria blepharophylla and the respective morphology and data spectra numbering (Figure S_)

\author{
Caryophyllene oxide (1): \\ Lichexanthone (2): \\ Spathulenol (3): \\ Mixture of $\beta$-sitosterol (4) and stigmasterol (5): \\ $O$-methylmoschatoline (6): \\ Lysicamine (7): \\ Nornuciferine (8): \\ Liriodenine (9): \\ Isocoreximine (10): \\ Subsessiline (11): \\ Isomoschatoline (12):
}

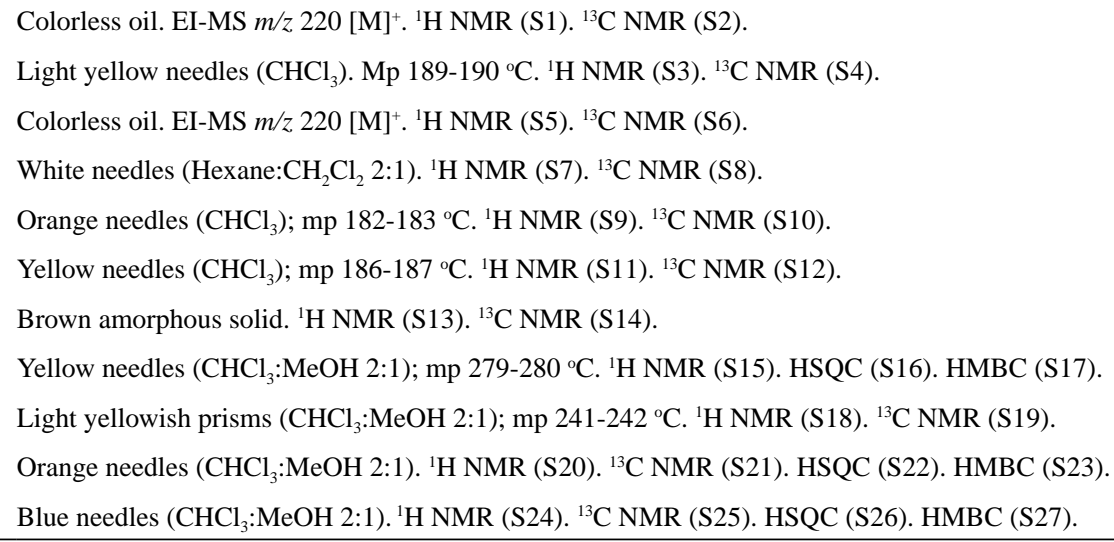




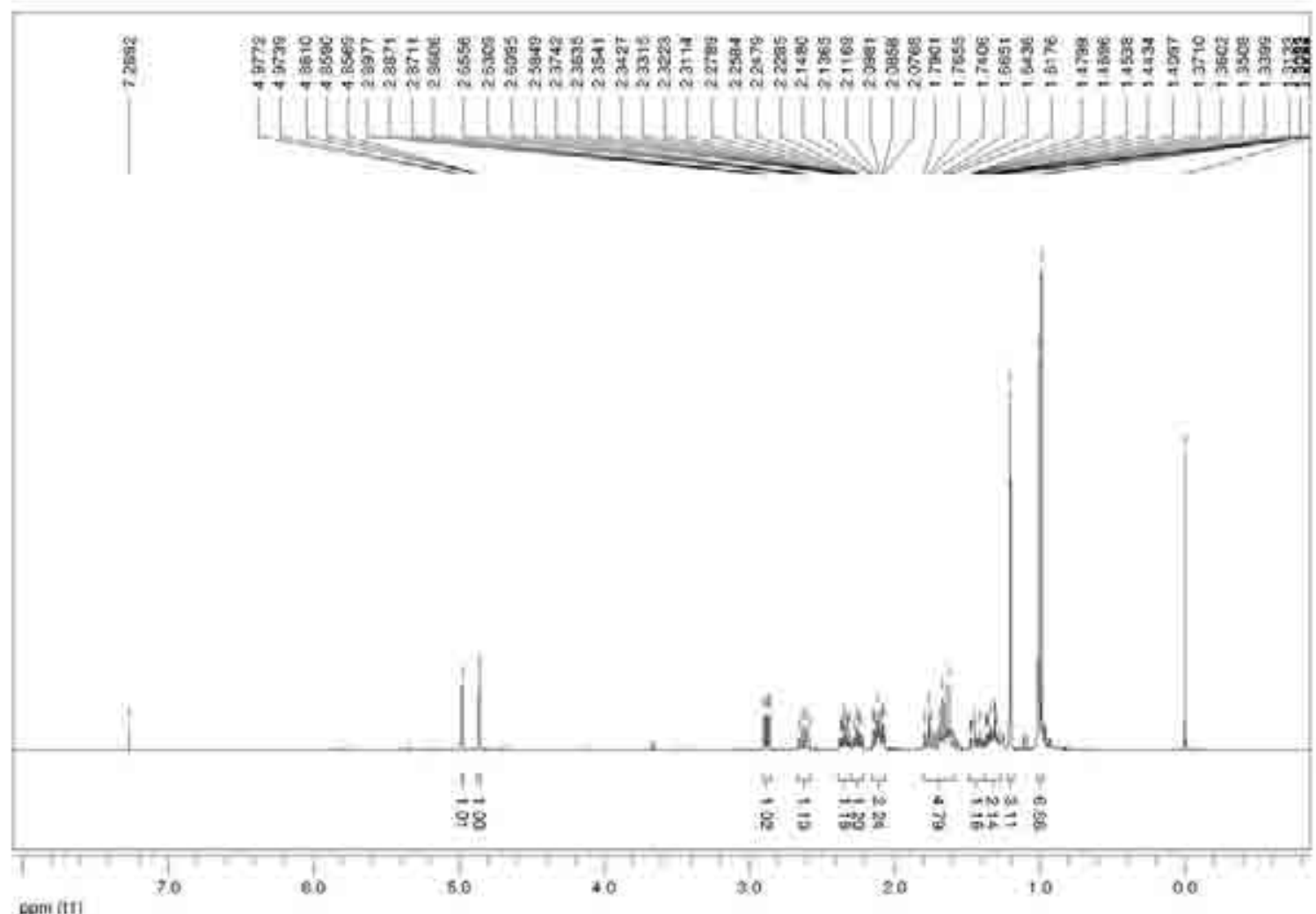

cpom (it)

Figure S1. ${ }^{~} \mathrm{H}$ NMR spectrum of compound $\mathbf{1}$ in $\mathrm{CDCl}_{3}$ at $400 \mathrm{MHz}$.

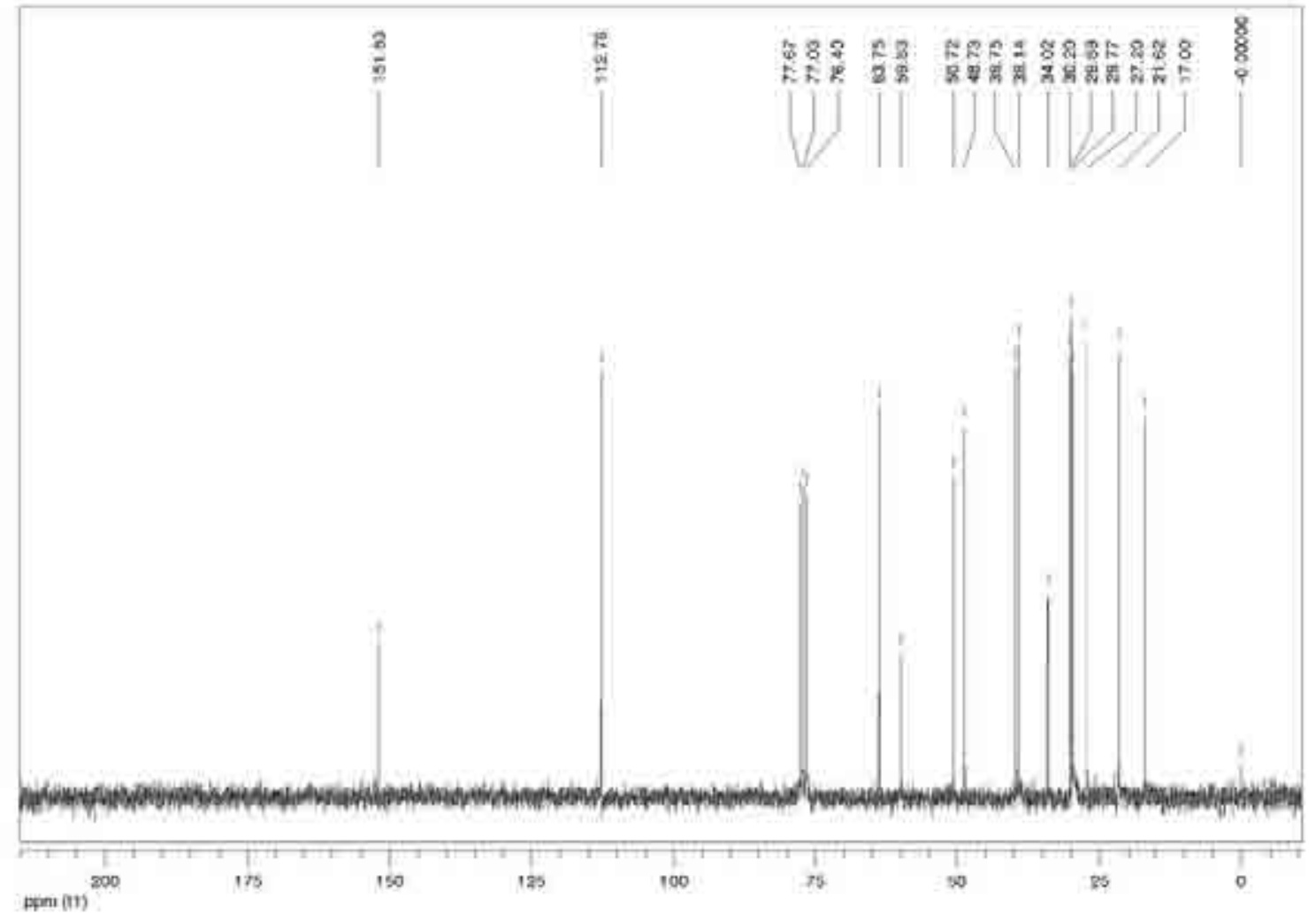

Figure S2. ${ }^{13} \mathrm{C}\left\{{ }^{1} \mathrm{H}\right\}$ NMR spectrum of compound $\mathbf{1}$ in $\mathrm{CDCl}_{3}$ at $100 \mathrm{MHz}$. 


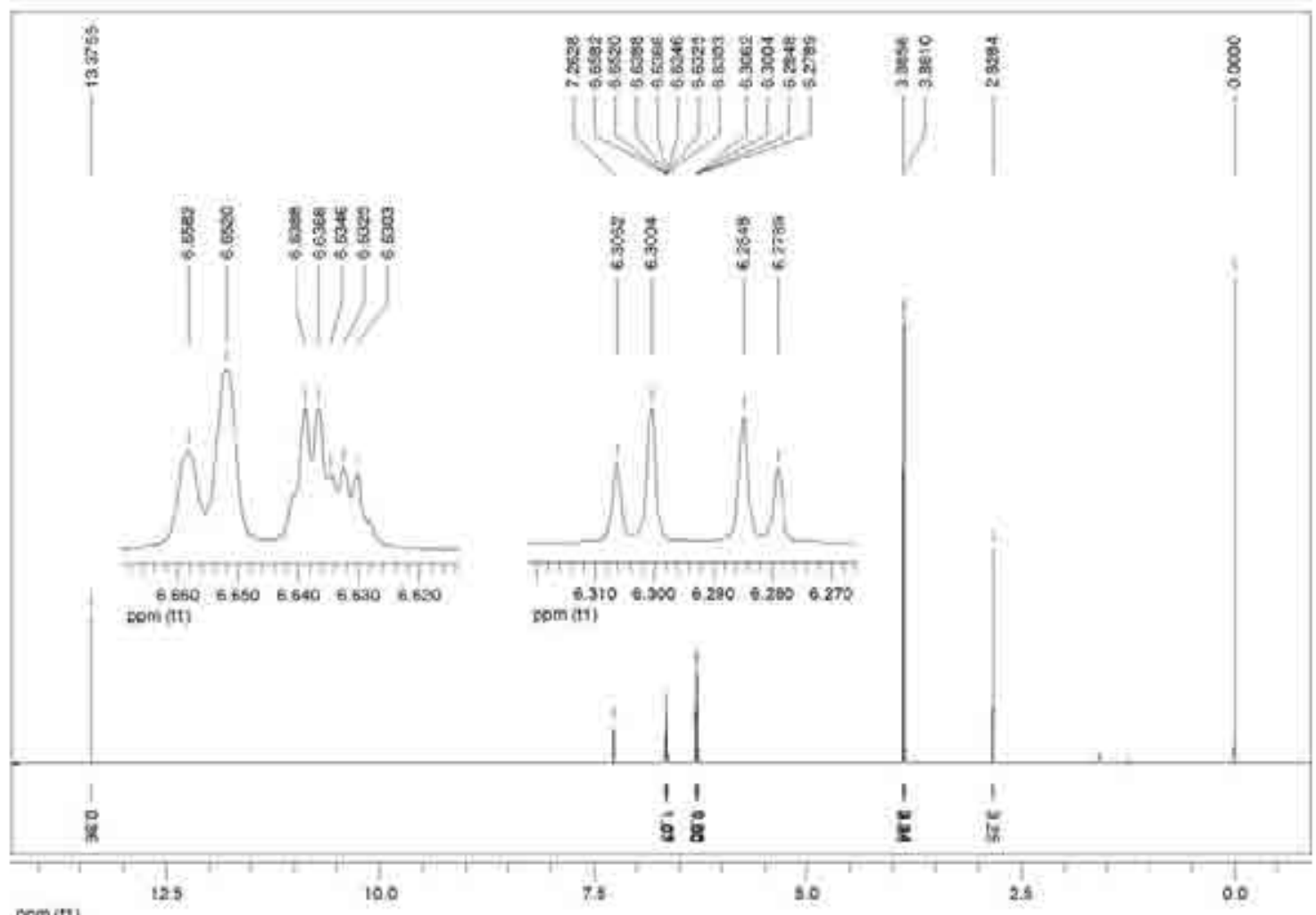

Figure S3. ${ }^{1} \mathrm{H}$ NMR spectrum of compound 2 in $\mathrm{CDCl}_{3}$ at $400 \mathrm{MHz}$.

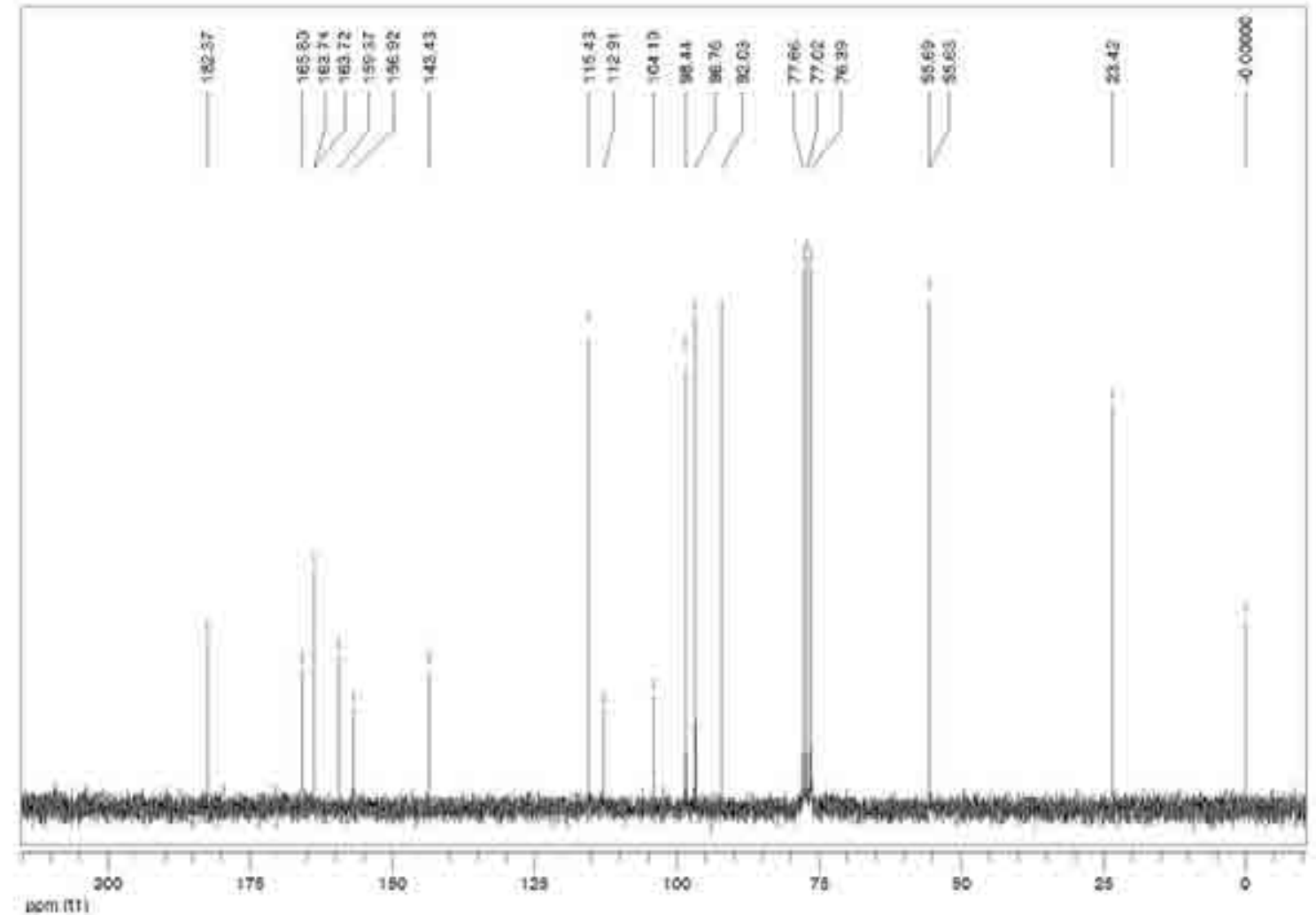

Figure S4. ${ }^{13} \mathrm{C}\left\{{ }^{1} \mathrm{H}\right\}$ NMR spectrum of compound 2 in $\mathrm{CDCl}_{3}$ at $100 \mathrm{MHz}$. 


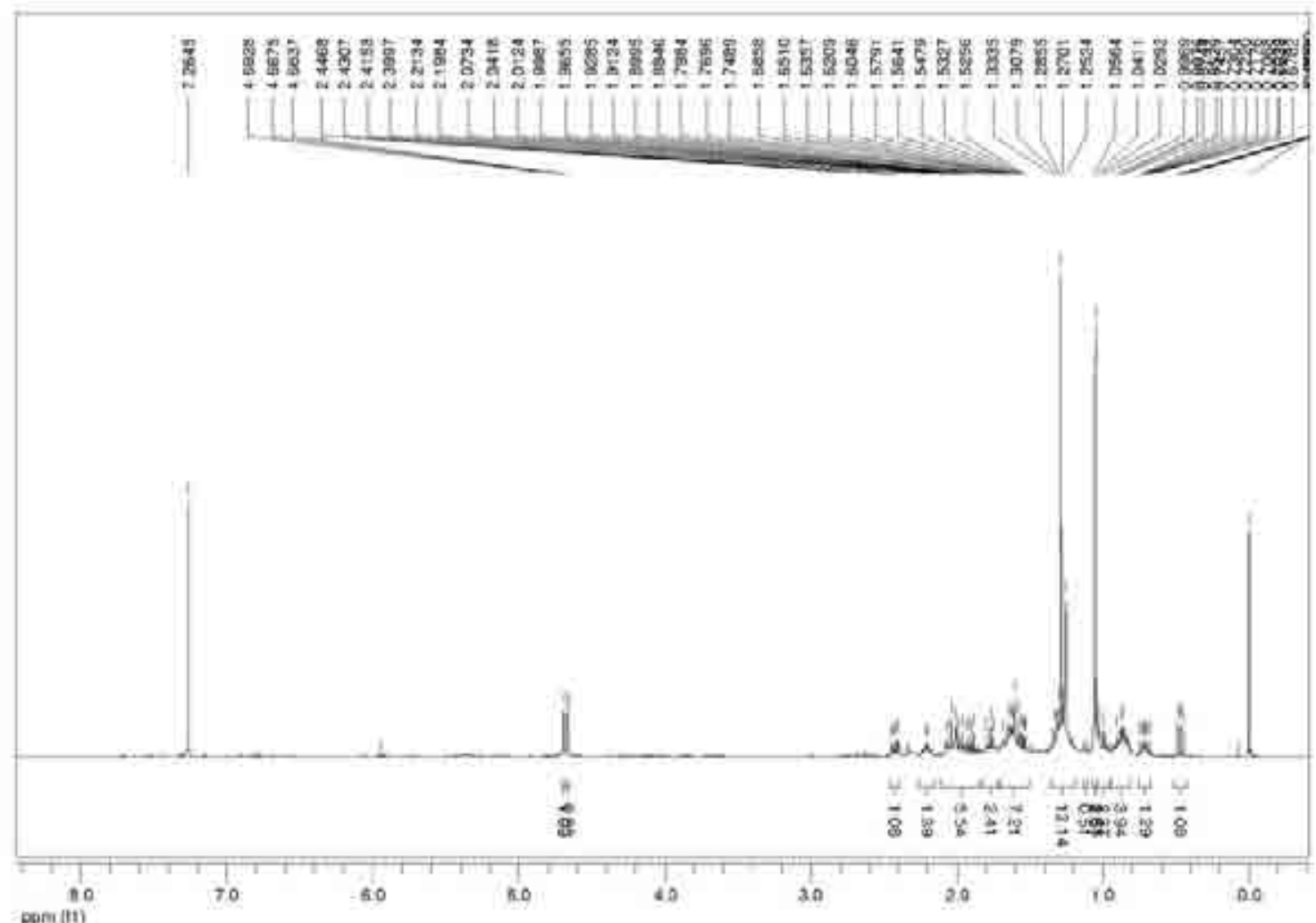

Figure S5. ${ }^{1} \mathrm{H}$ NMR spectrum of compound 3 in $\mathrm{CDCl}_{3}$ at $400 \mathrm{MHz}$.

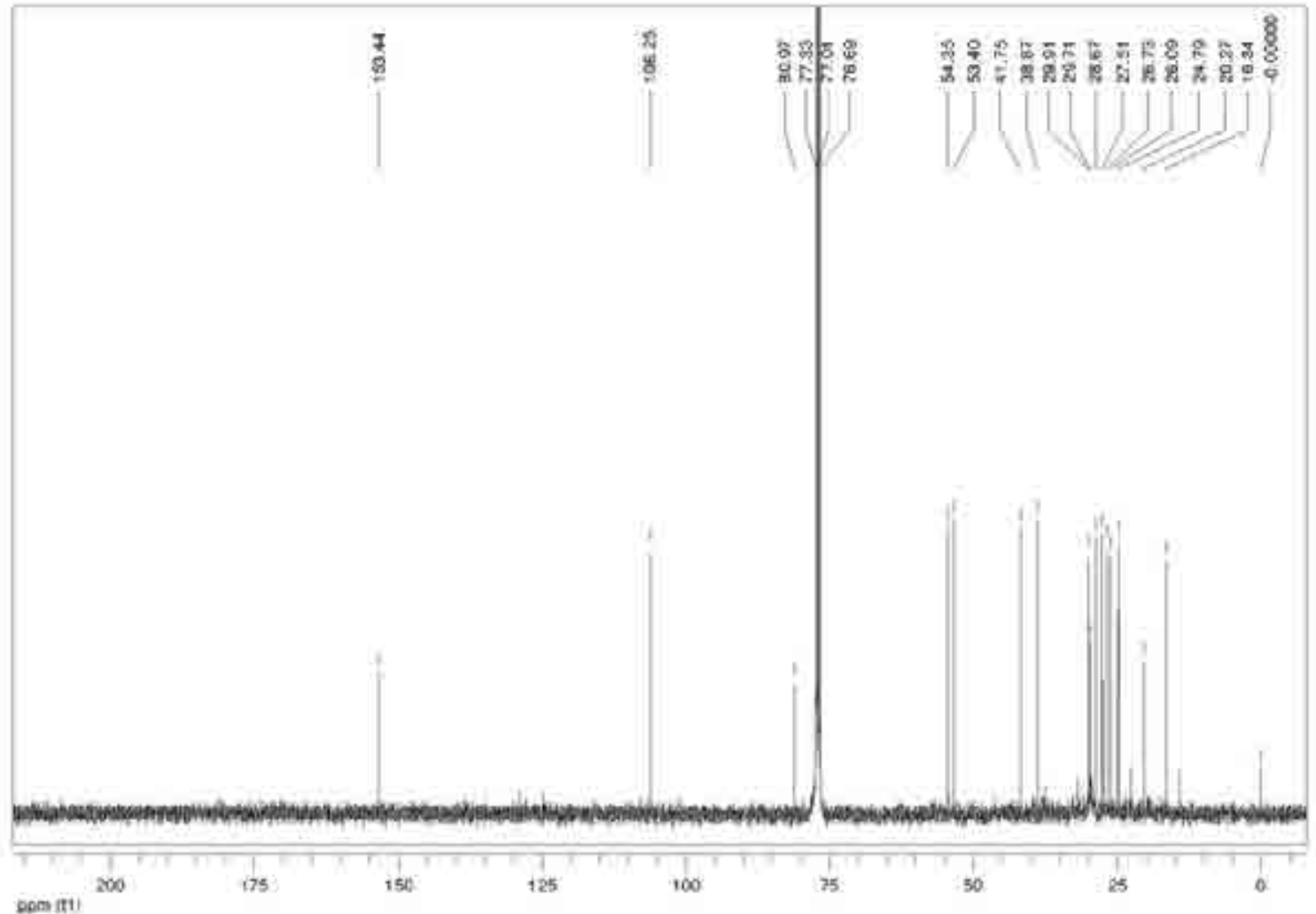

Figure S6. ${ }^{13} \mathrm{C}\left\{{ }^{1} \mathrm{H}\right\}$ NMR spectrum of compound $\mathbf{3}$ in $\mathrm{CDCl}_{3}$ at $100 \mathrm{MHz}$. 


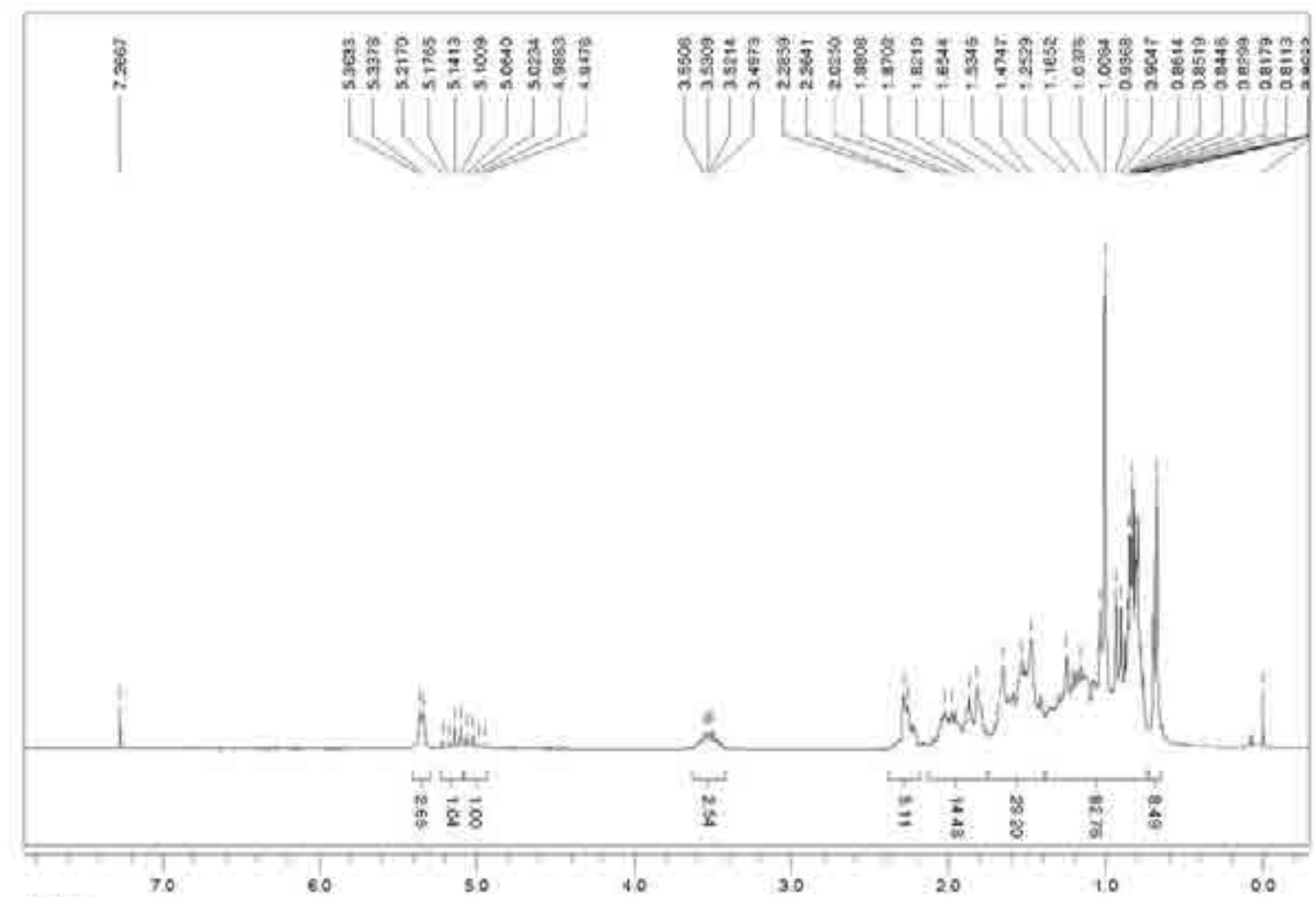

opm Itti

Figure S7. ${ }^{1} \mathrm{H}$ NMR spectrum of the mixture of compounds 4 and $\mathbf{5}$ in $\mathrm{CDCl}_{3}$ at $200 \mathrm{MHz}$.

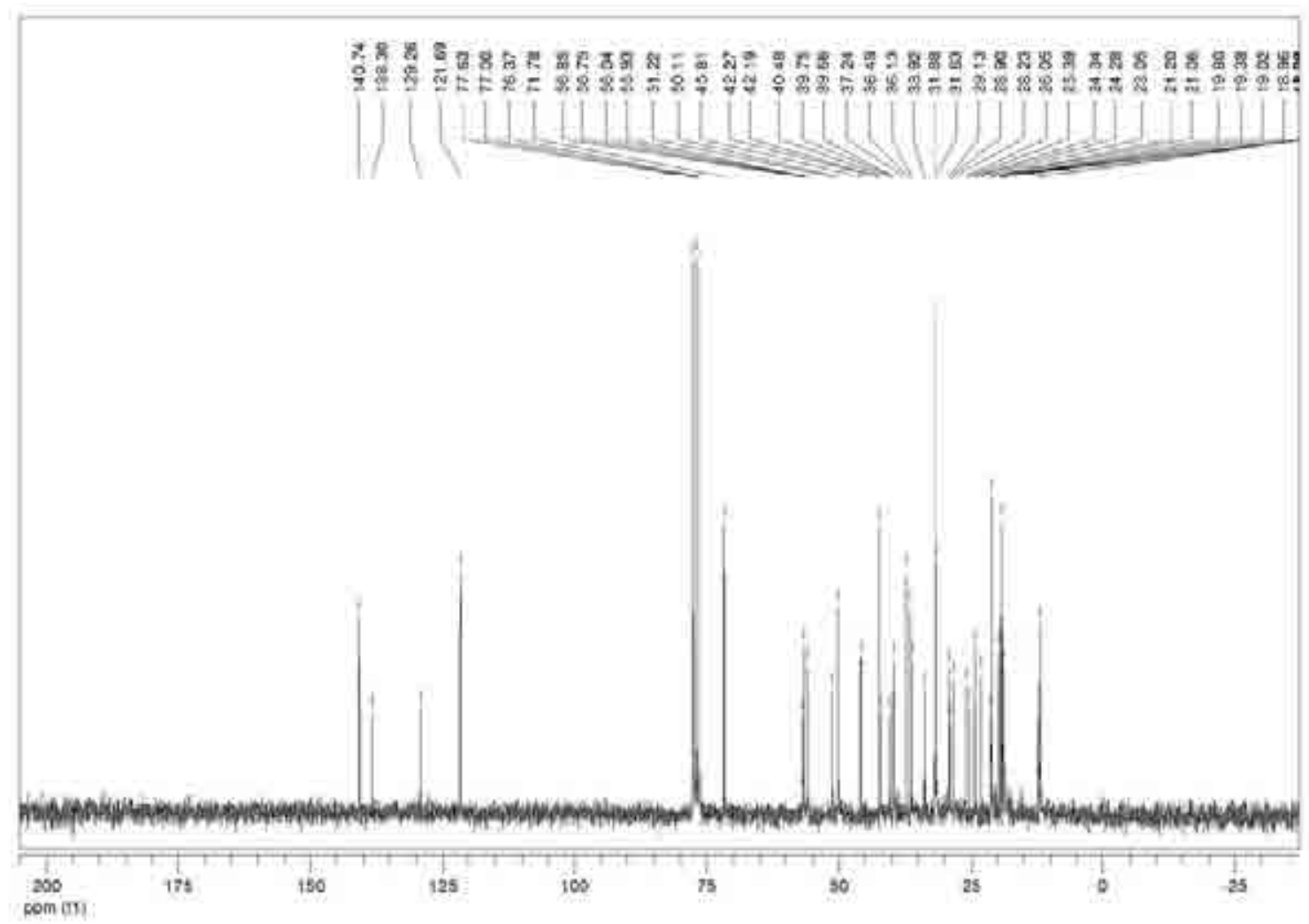

Figure S8. ${ }^{13} \mathrm{C}\left\{{ }^{1} \mathrm{H}\right\}$ NMR spectrum of the mixture of compounds $\mathbf{4}$ and $\mathbf{5}$ in $\mathrm{CDCl}_{3}$ at $50 \mathrm{MHz}$. 


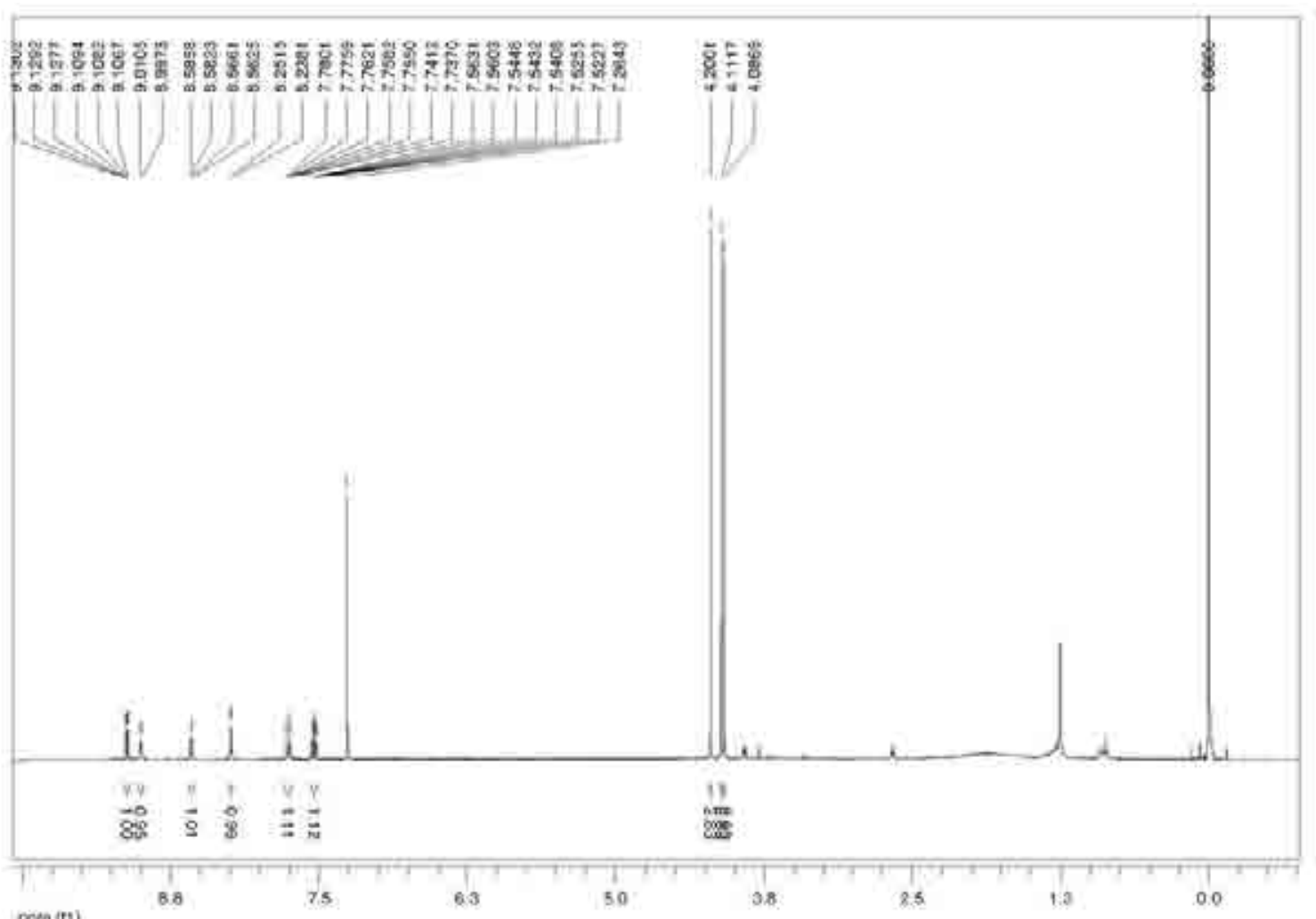

Figure S9. ${ }^{1} \mathrm{H}$ NMR spectrum of compound 6 in $\mathrm{CDCl}_{3}$ at $400 \mathrm{MHz}$.

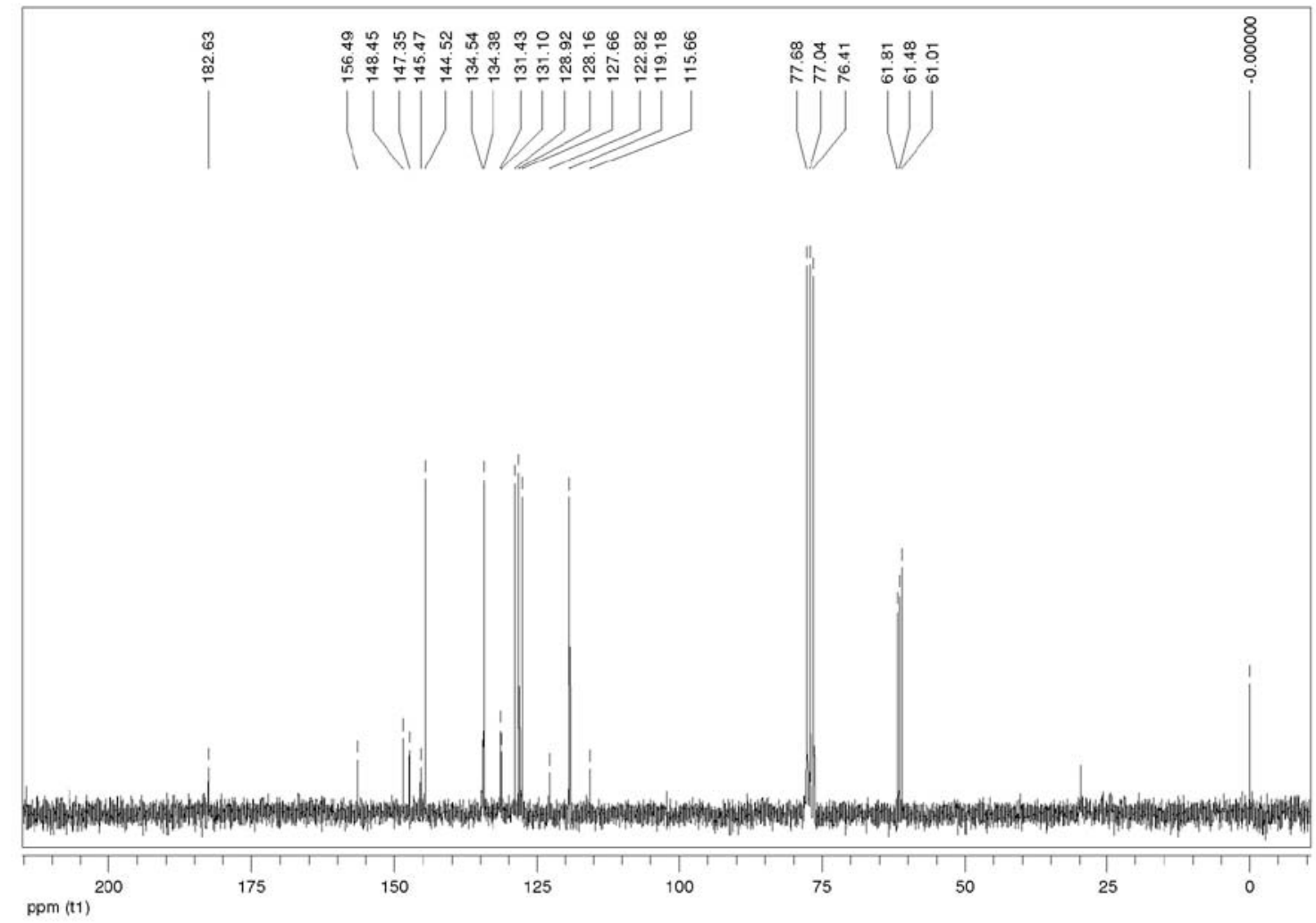

Figure S10. ${ }^{13} \mathrm{C}\left\{{ }^{1} \mathrm{H}\right\}$ NMR spectrum of compound 6 in $\mathrm{CDCl}_{3}$ at $100 \mathrm{MHz}$. 


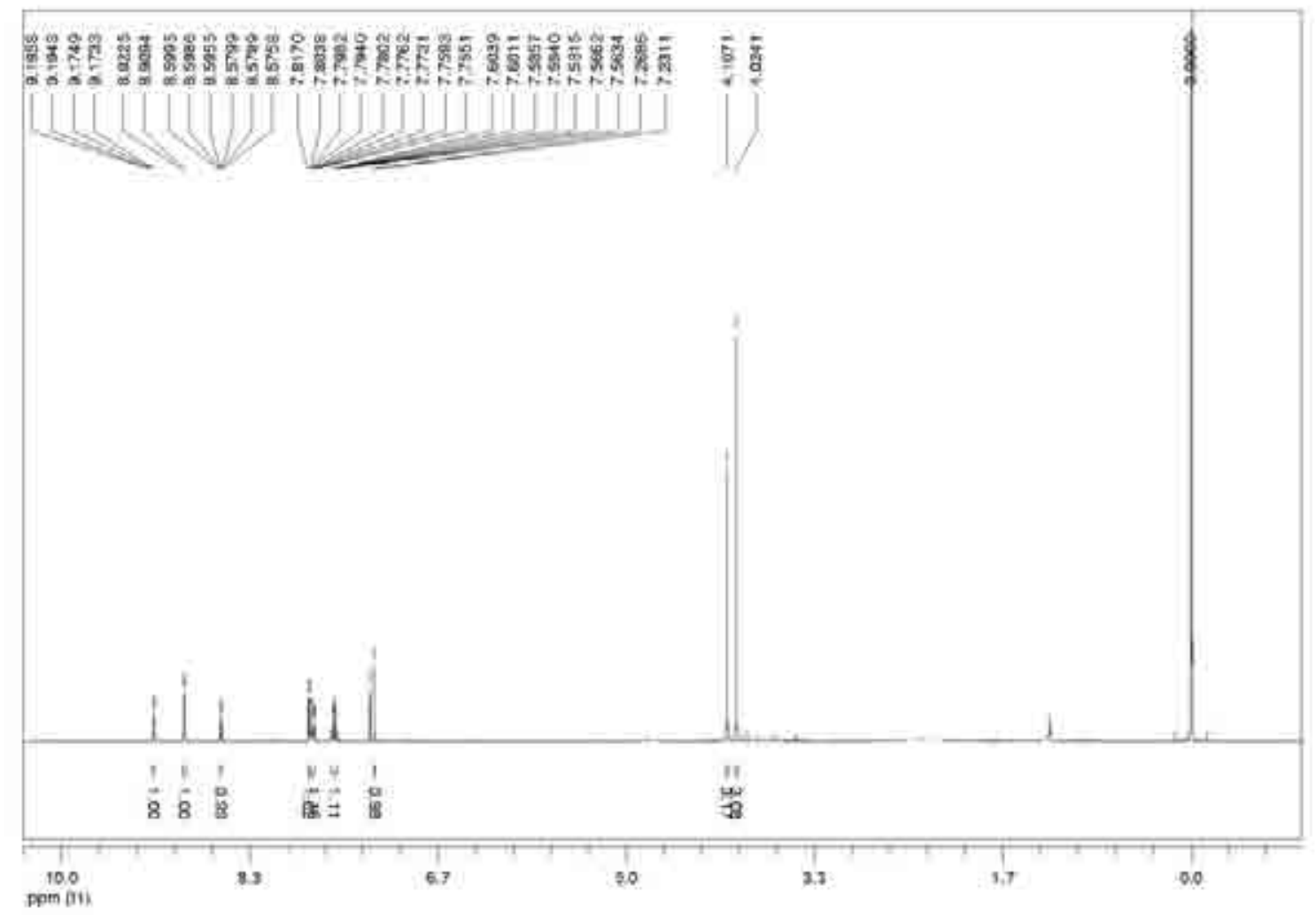

Figure S11. ${ }^{1} \mathrm{H}$ NMR spectrum of compound 7 in $\mathrm{CDCl}_{3}$ at $400 \mathrm{MHz}$.

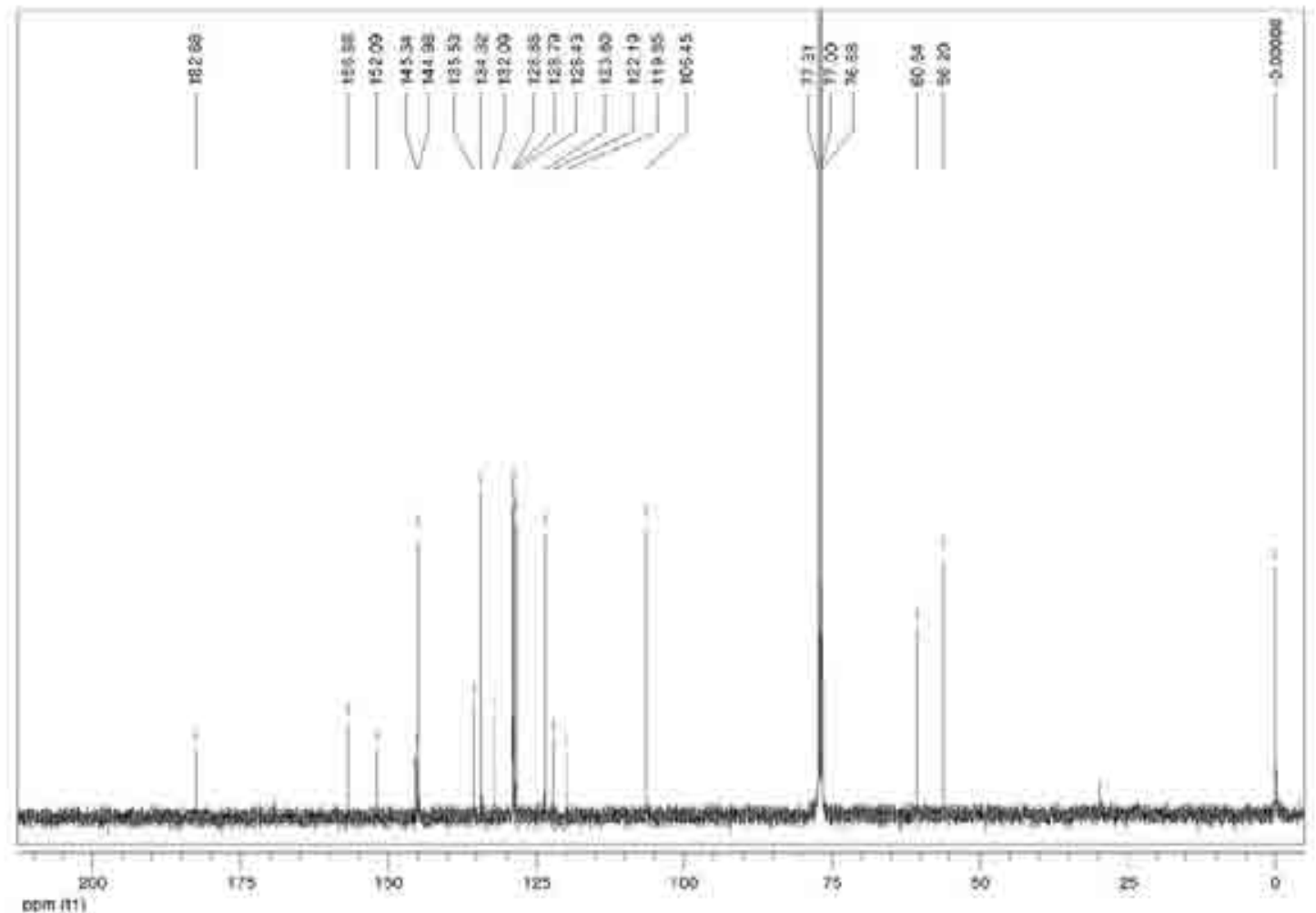

Figure S12. ${ }^{13} \mathrm{C}\left\{{ }^{1} \mathrm{H}\right\}$ NMR spectrum of compound 7 in $\mathrm{CDCl}_{3}$ at $100 \mathrm{MHz}$. 


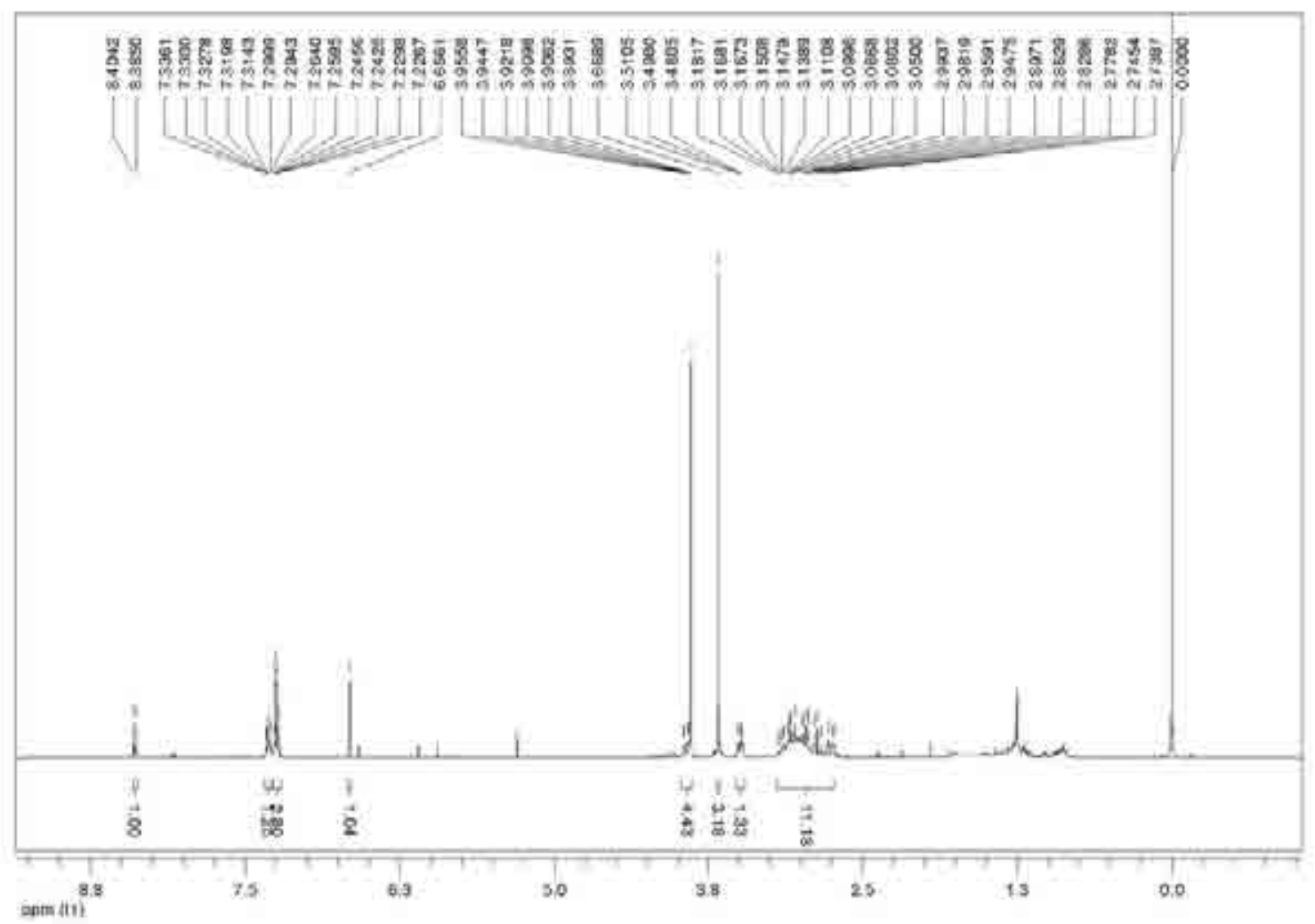

Figure S13. ${ }^{1} \mathrm{H}$ NMR spectrum of compound 8 in $\mathrm{CDCl}_{3}$ at $400 \mathrm{MHz}$.

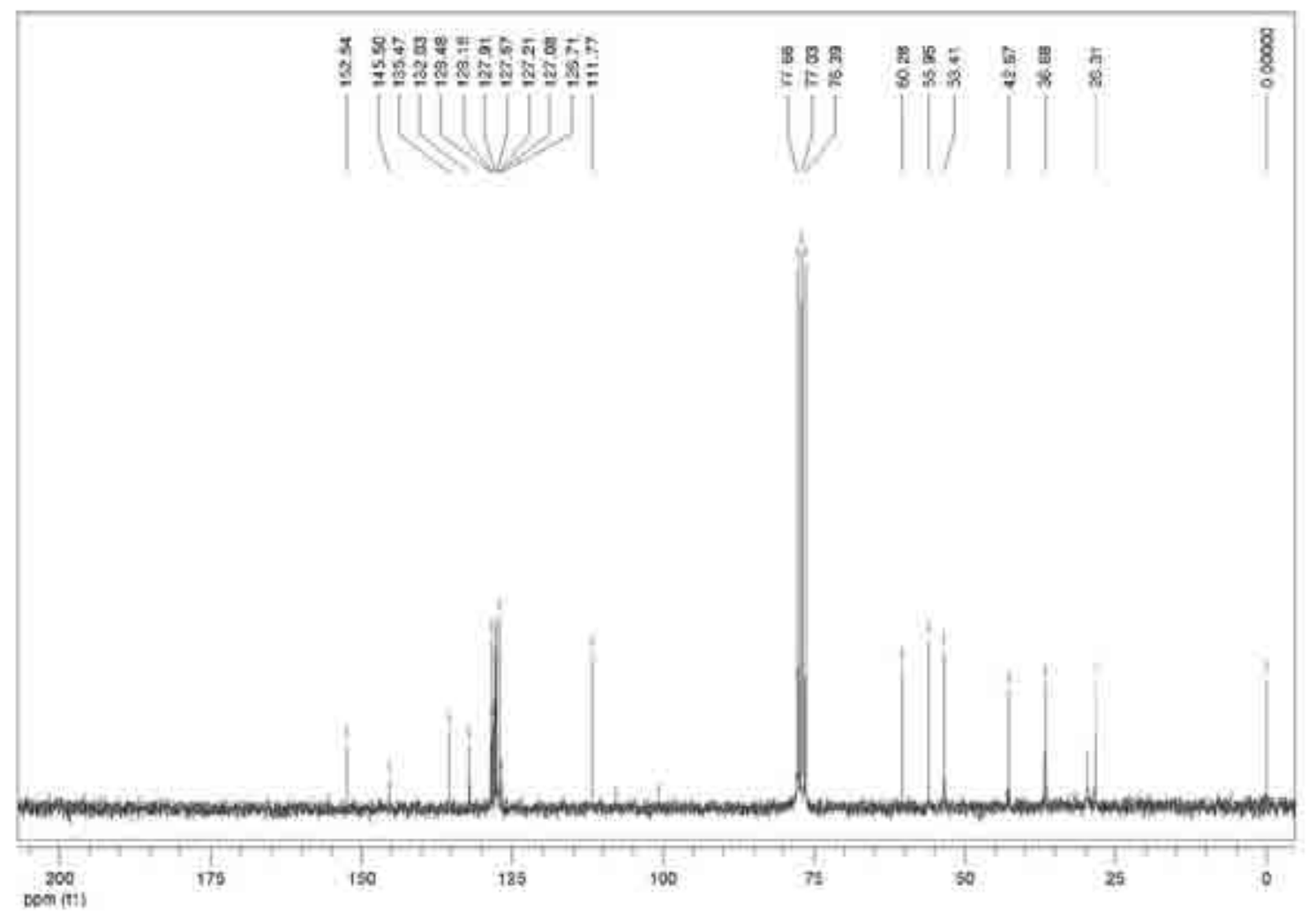

Figure S14. ${ }^{13} \mathrm{C}\left\{{ }^{1} \mathrm{H}\right\}$ NMR spectrum of compound $\mathbf{8}$ in $\mathrm{CDCl}_{3}$ at $100 \mathrm{MHz}$. 


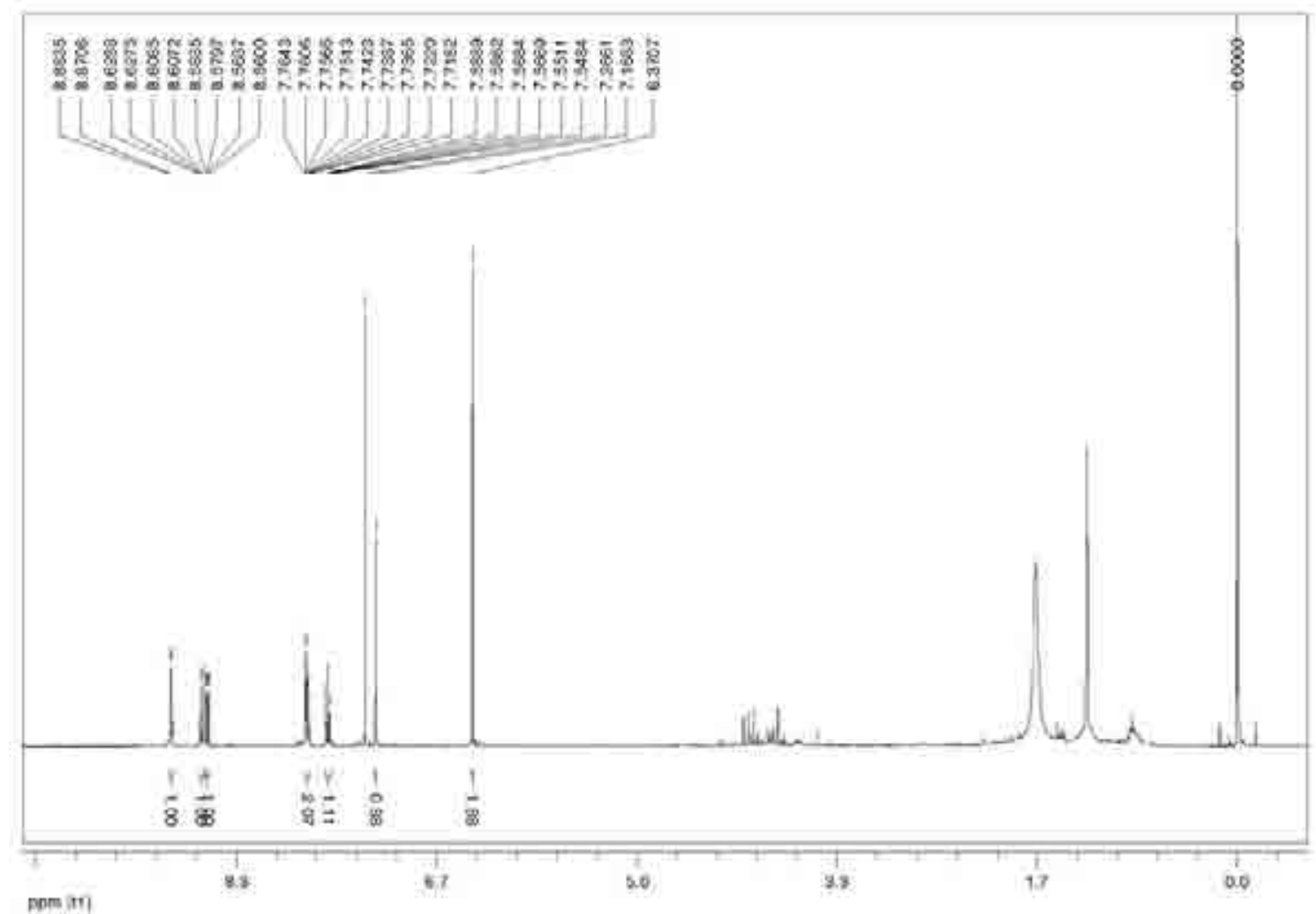

Figure S15. ${ }^{1} \mathrm{H}$ NMR spectrum of compound 9 in $\mathrm{CDCl}_{3}$ at $400 \mathrm{MHz}$.

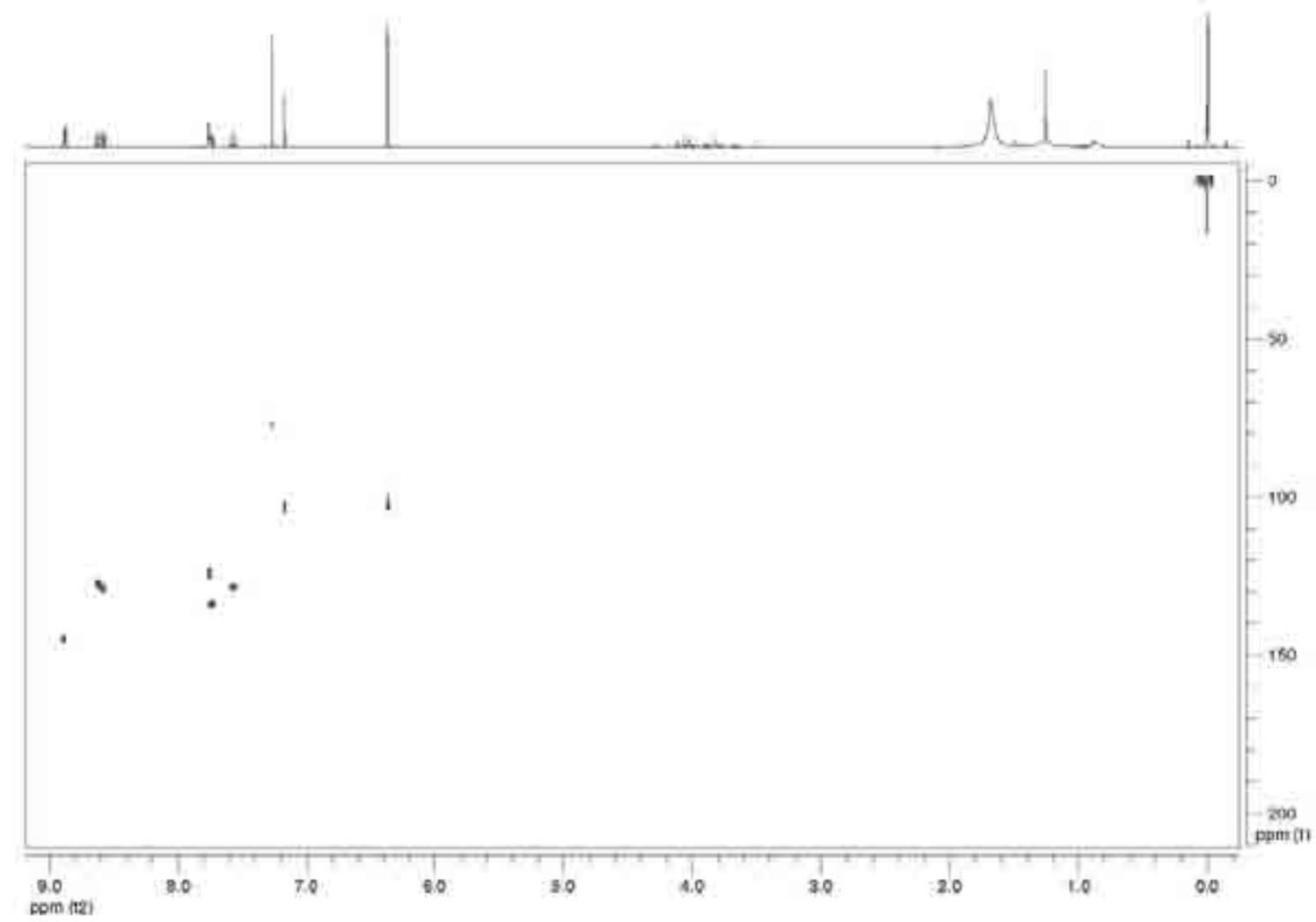

Figure S16. ${ }^{1} \mathrm{H}-{ }^{13} \mathrm{C}$ one-bond correlation map from HSQC NMR experiment of compound 9 in $\mathrm{CDCl}_{3}$ at 400 and $100 \mathrm{MHz}$. 


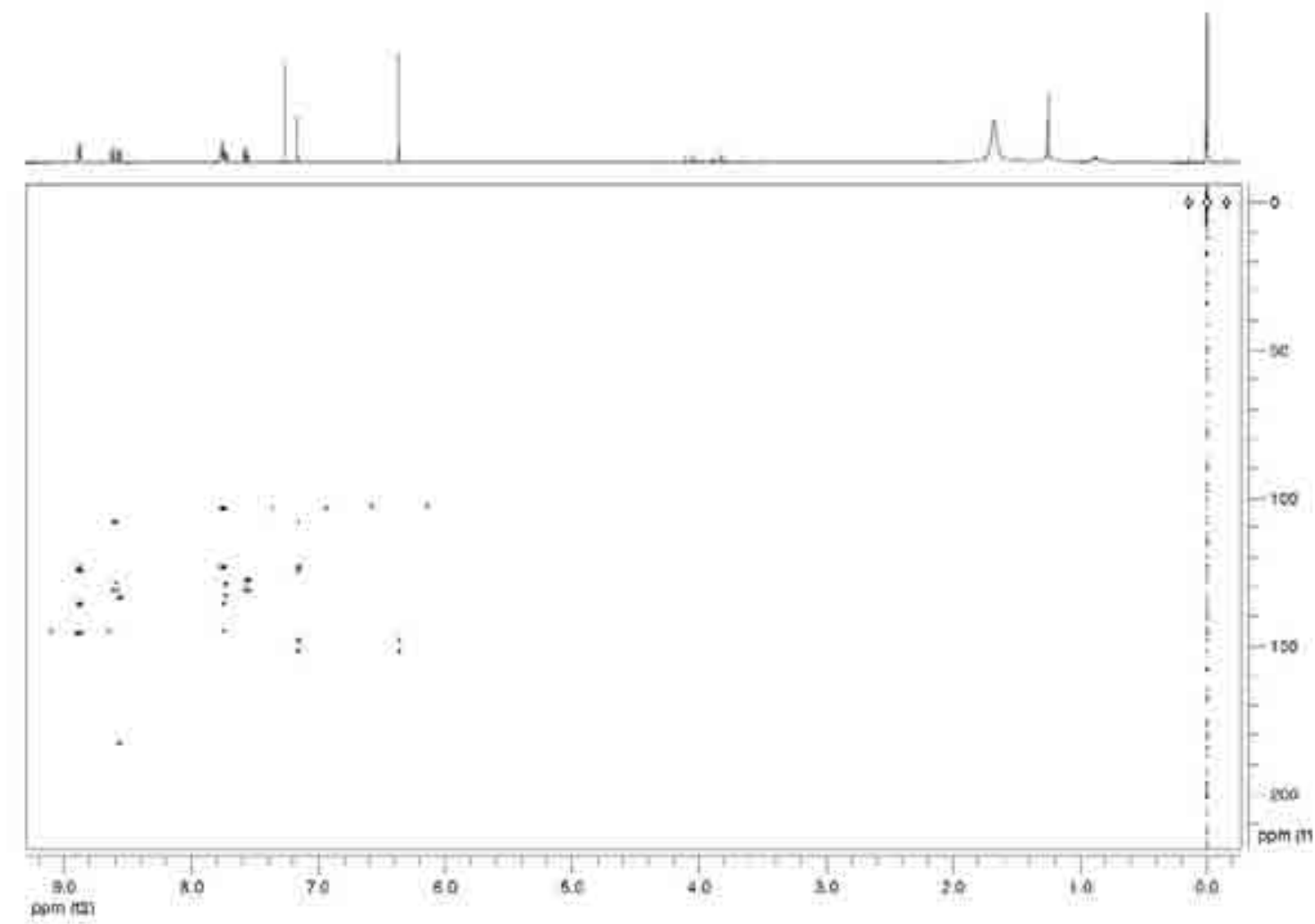

Figure S17. ${ }^{1} \mathrm{H}-{ }^{13} \mathrm{C}$ long-range correlation map from $\mathrm{HMBC}$ NMR experiment of compound $\mathbf{9}$ in $\mathrm{CDCl}_{3}$ at 400 and $100 \mathrm{MHz}$.

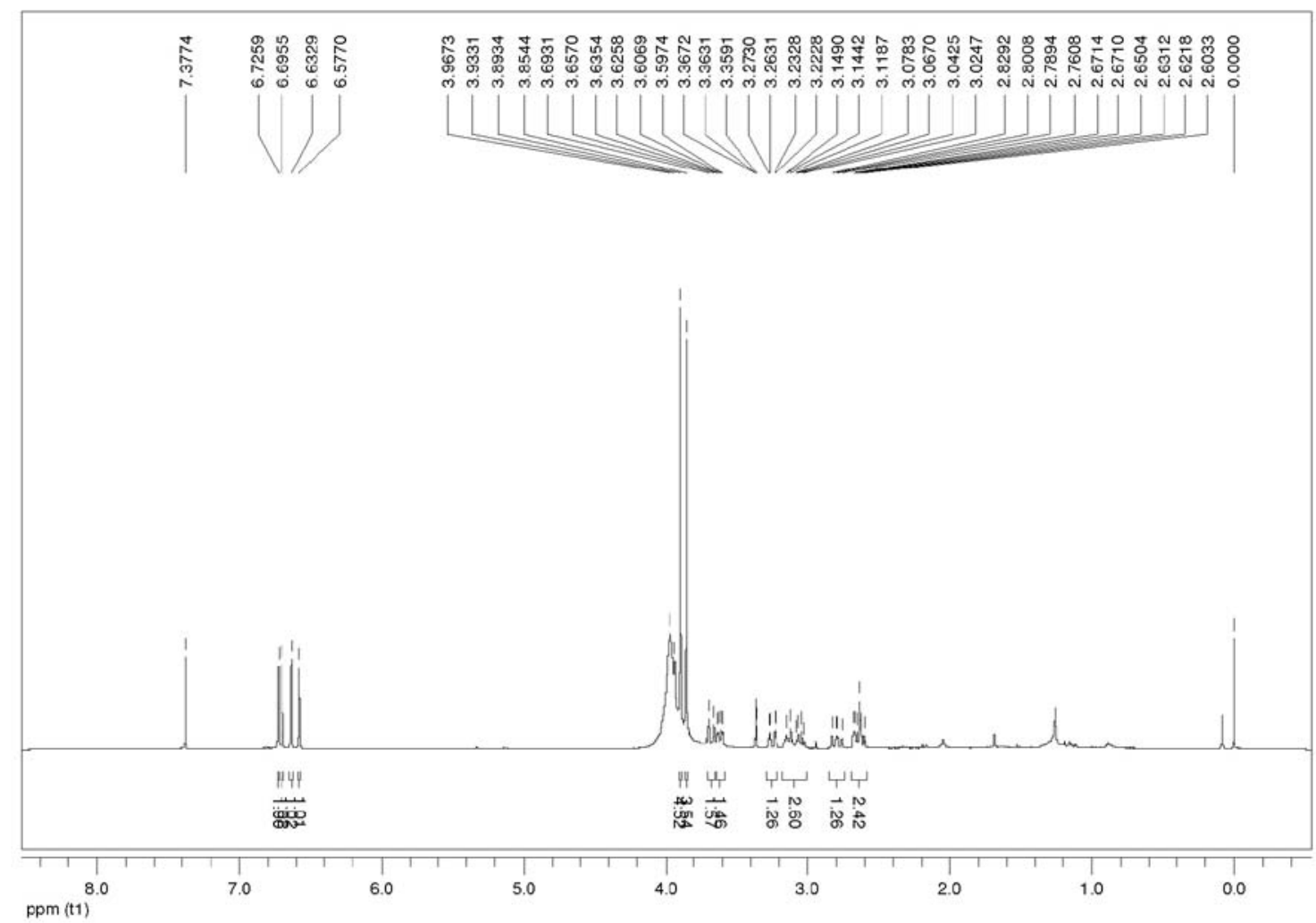

Figure S18. ${ }^{1} \mathrm{H}$ NMR spectrum of compound 10 in $\mathrm{CDCl}_{3}+$ drops of $\mathrm{CD}_{3} \mathrm{OD}$ at $400 \mathrm{MHz}$. 


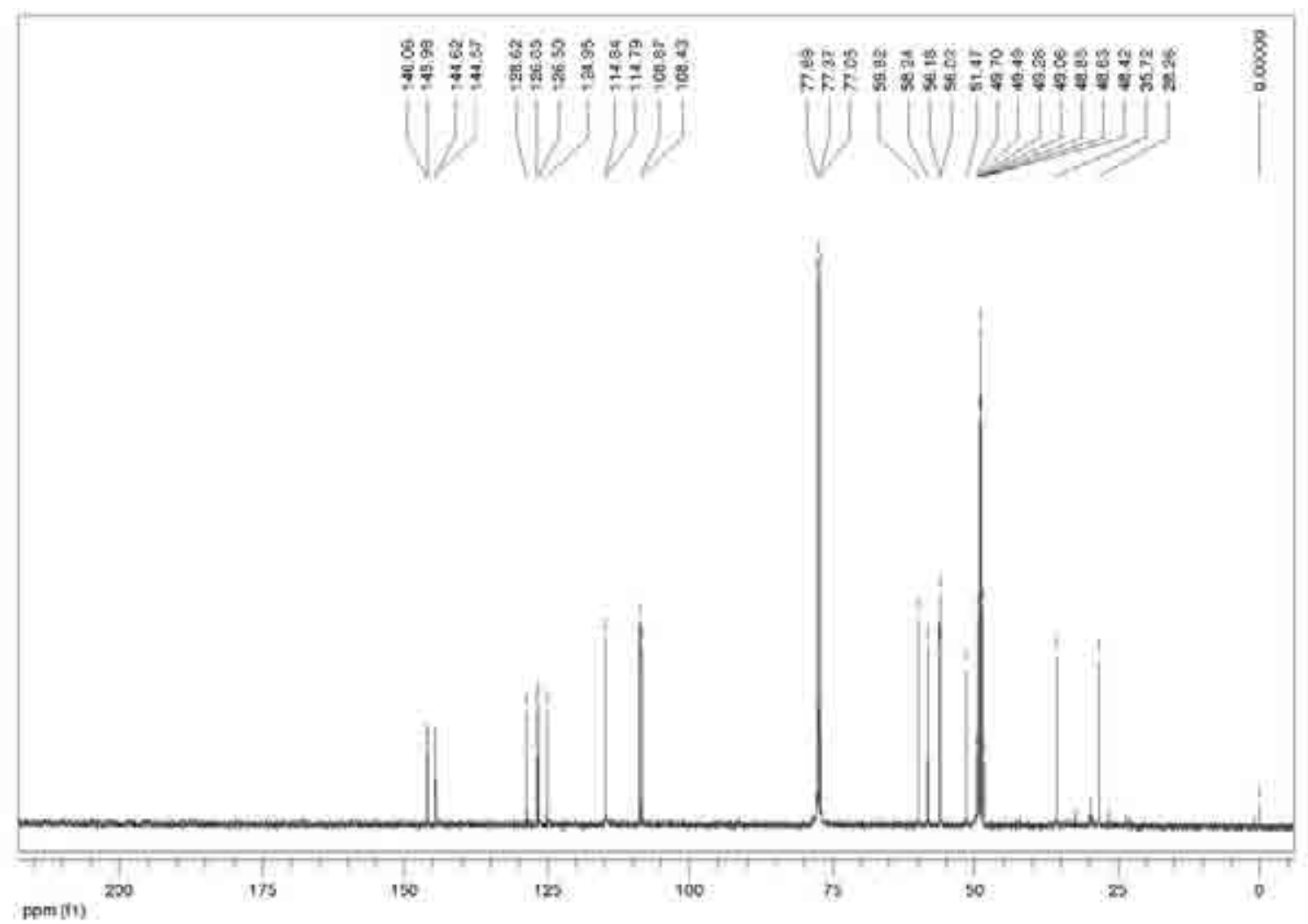

Figure S19. ${ }^{13} \mathrm{C}\left\{{ }^{1} \mathrm{H}\right\}$ NMR spectrum of compound 10 in $\mathrm{CDCl}_{3}+$ drops of $\mathrm{CD}_{3} \mathrm{OD}$ at $100 \mathrm{MHz}$.

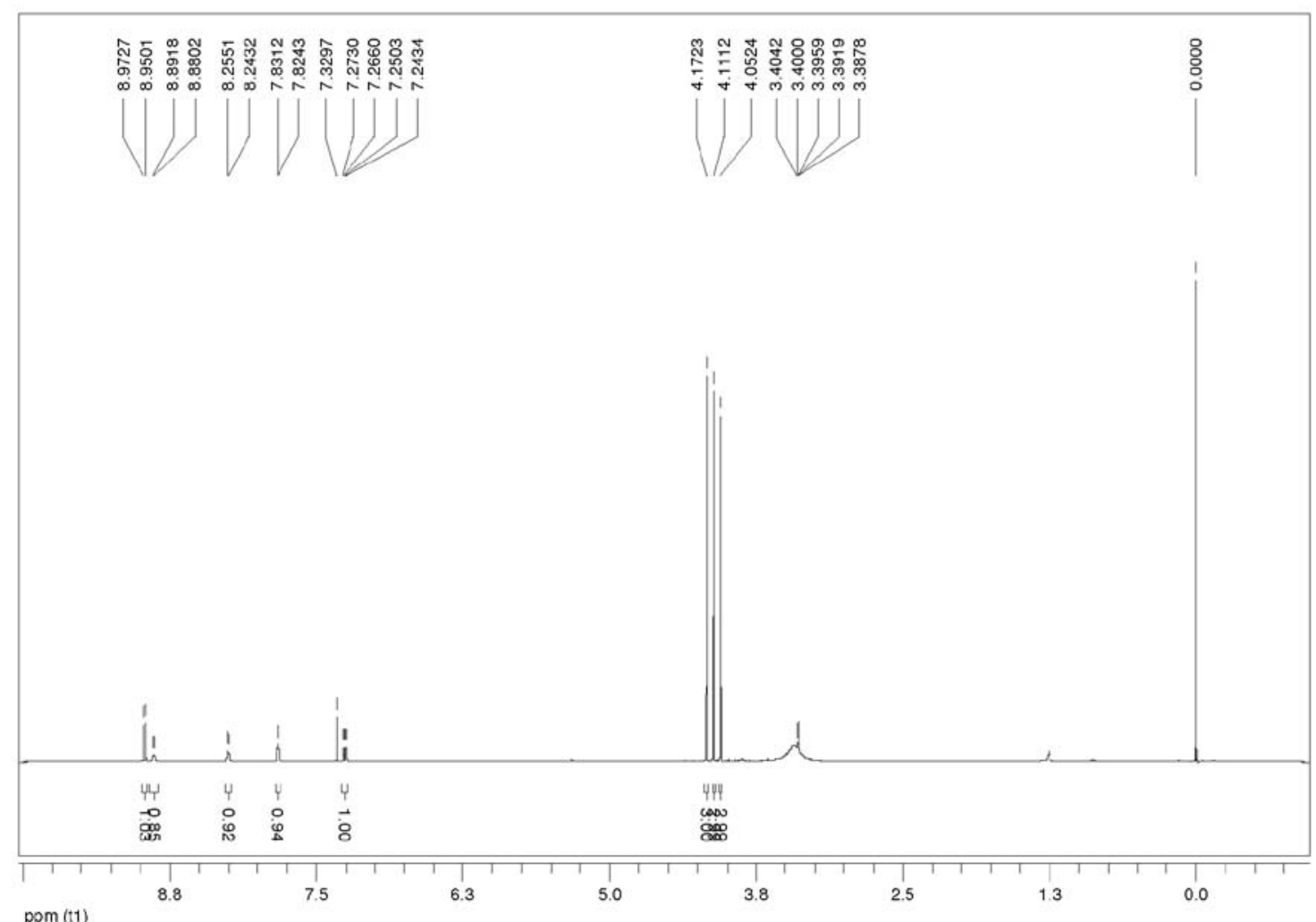

Figure S20. ${ }^{1} \mathrm{H}$ NMR spectrum of compound 11 in $\mathrm{CDCl}_{3}+$ drops of $\mathrm{CD}_{3} \mathrm{OD}$ at $400 \mathrm{MHz}$. 


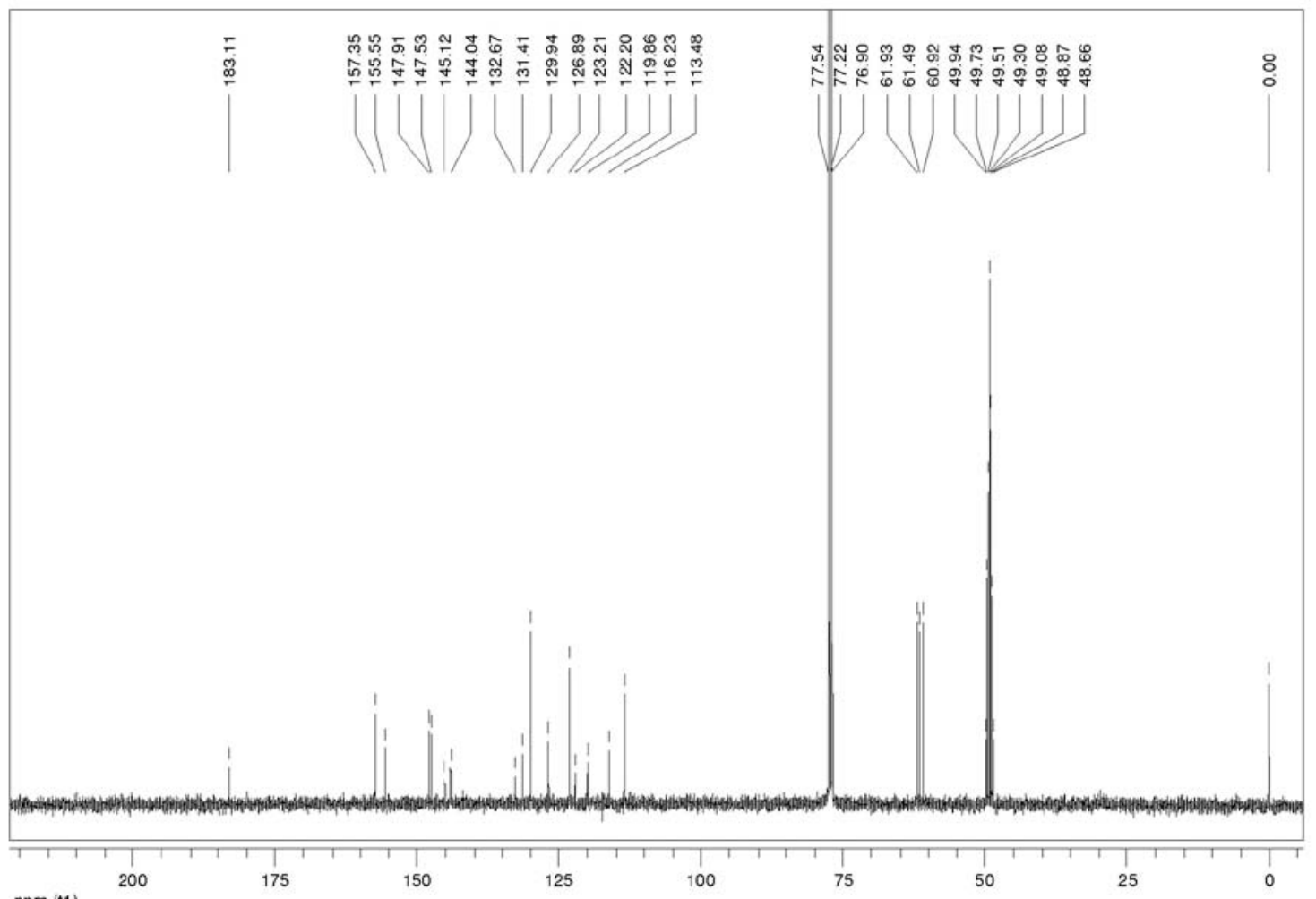

$\mathrm{ppm}\langle\mathrm{t} 1\rangle$

Figure S21. ${ }^{13} \mathrm{C}\left\{{ }^{1} \mathrm{H}\right\}$ NMR spectrum of compound 11 in $\mathrm{CDCl}_{3}+$ drops of $\mathrm{CD}_{3} \mathrm{OD}$ at $100 \mathrm{MHz}$.

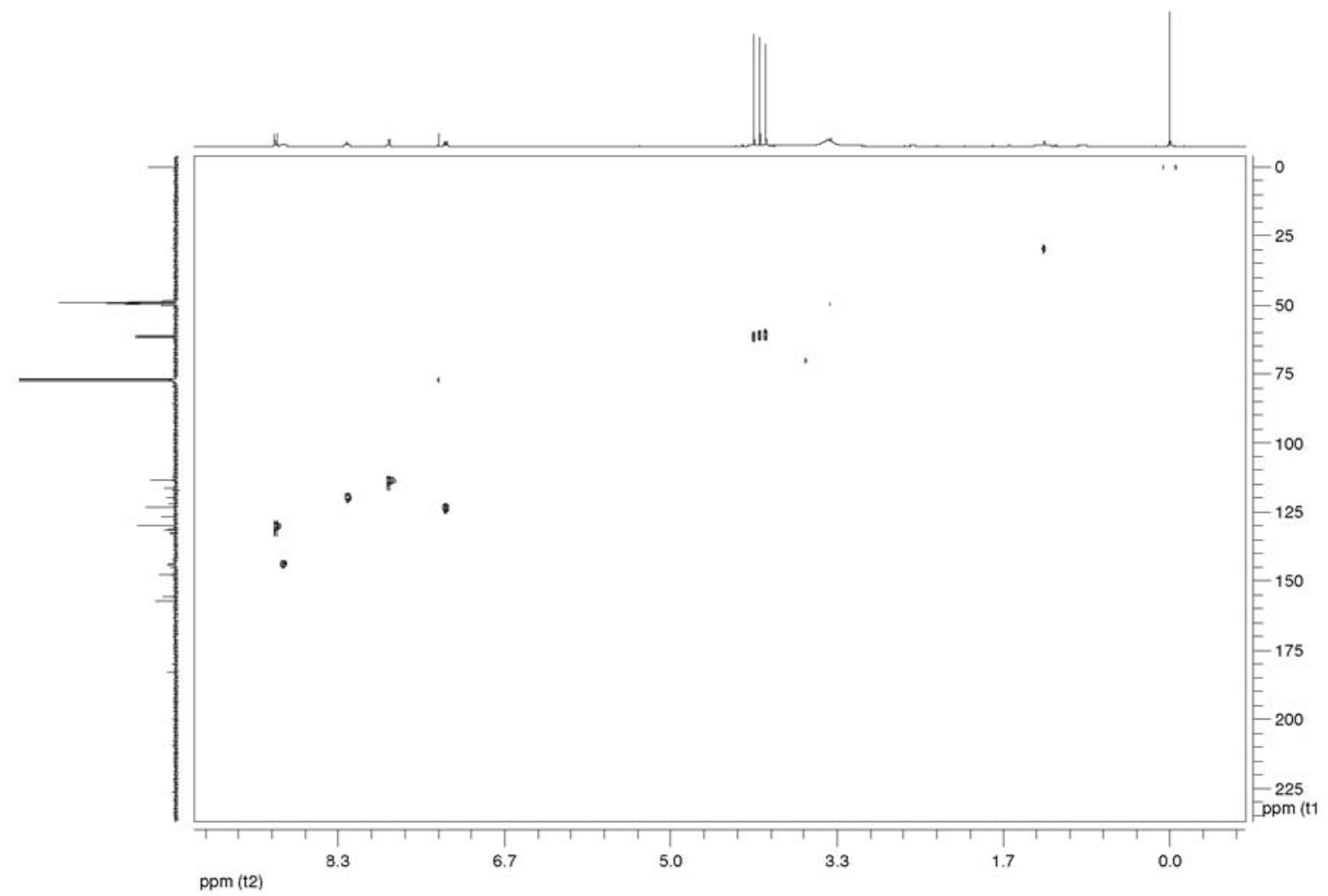

Figure S22. ${ }^{1} \mathrm{H}^{-13} \mathrm{C}$ one-bond correlation map from HSQC NMR experiment of compound 11 in $\mathrm{CDCl}_{3}+\operatorname{drops}_{\text {of }} \mathrm{CD}_{3} \mathrm{OD}$ at 400 and $100 \mathrm{MHz}$. 


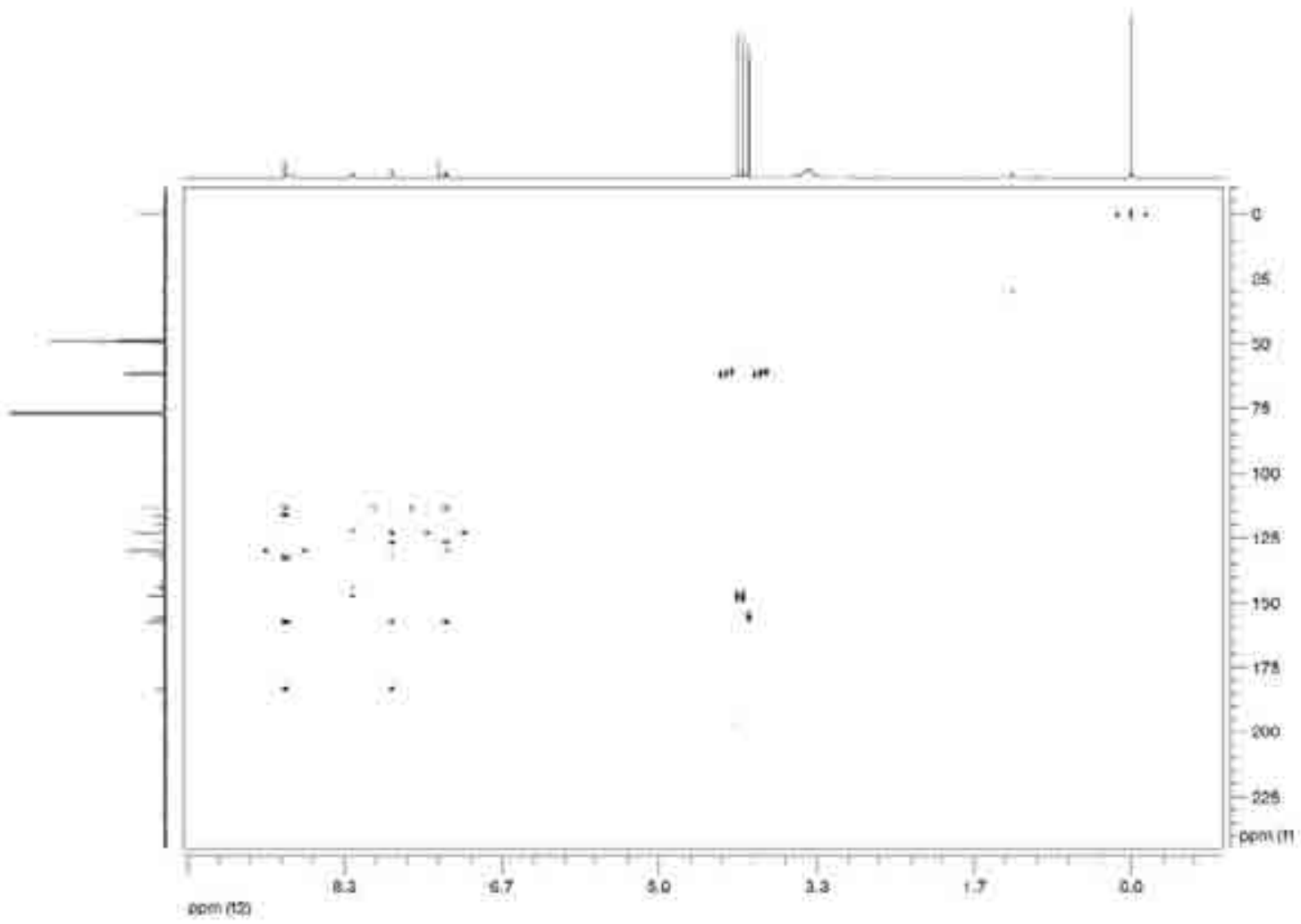

Figure S23. ${ }^{1} \mathrm{H}-{ }^{13} \mathrm{C}$ long-range correlation map from $\mathrm{HMBC}$ NMR experiment of compound $\mathbf{1 1}$ in $\mathrm{CDCl}_{3}+$ drops of $\mathrm{CD}_{3} \mathrm{OD}$ at 400 and $100 \mathrm{MHz}$.

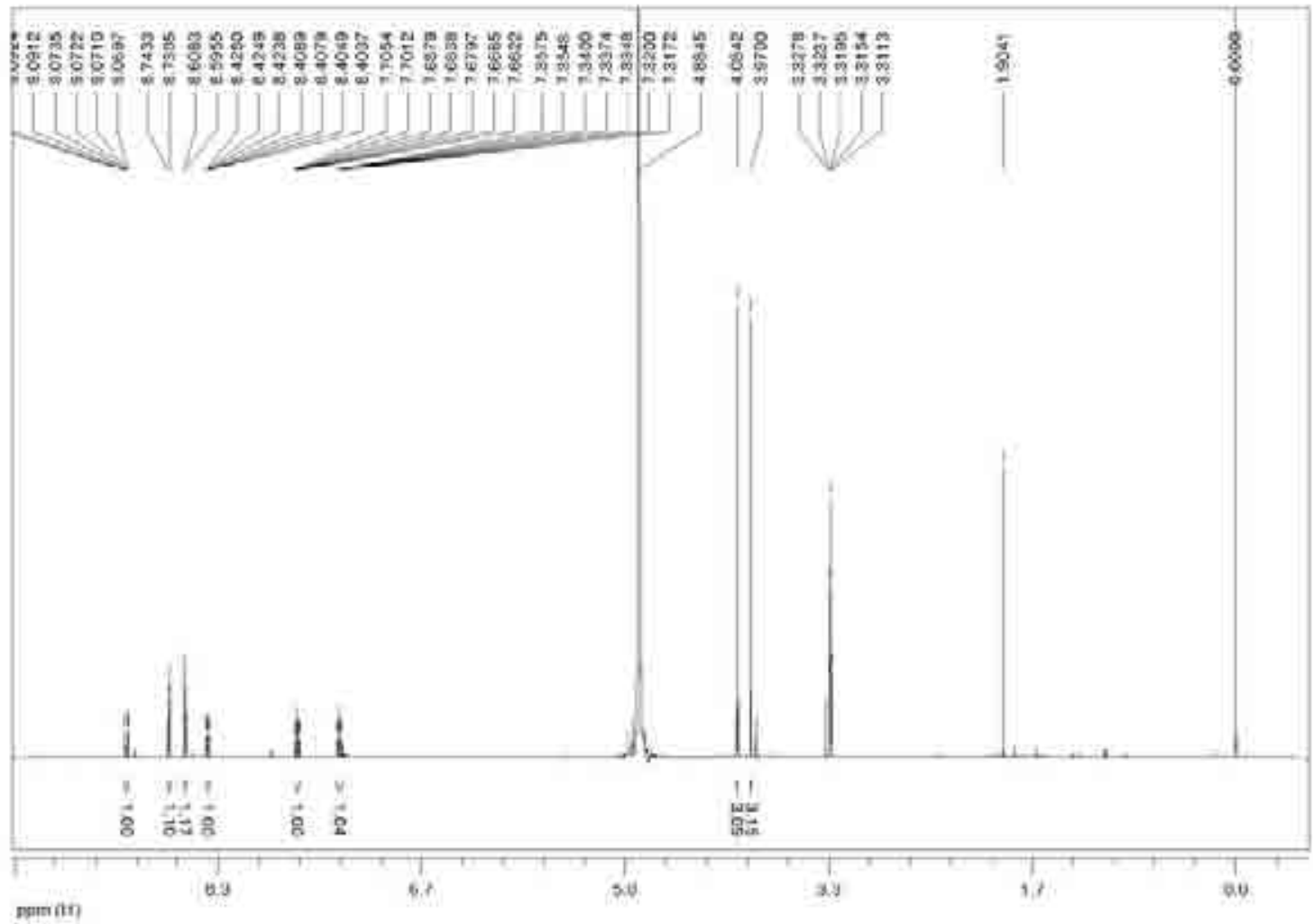

Figure S24. ${ }^{1} \mathrm{H}$ NMR spectrum of compound 12 in $\mathrm{CD}_{3} \mathrm{OD}$ at $400 \mathrm{MHz}$. 


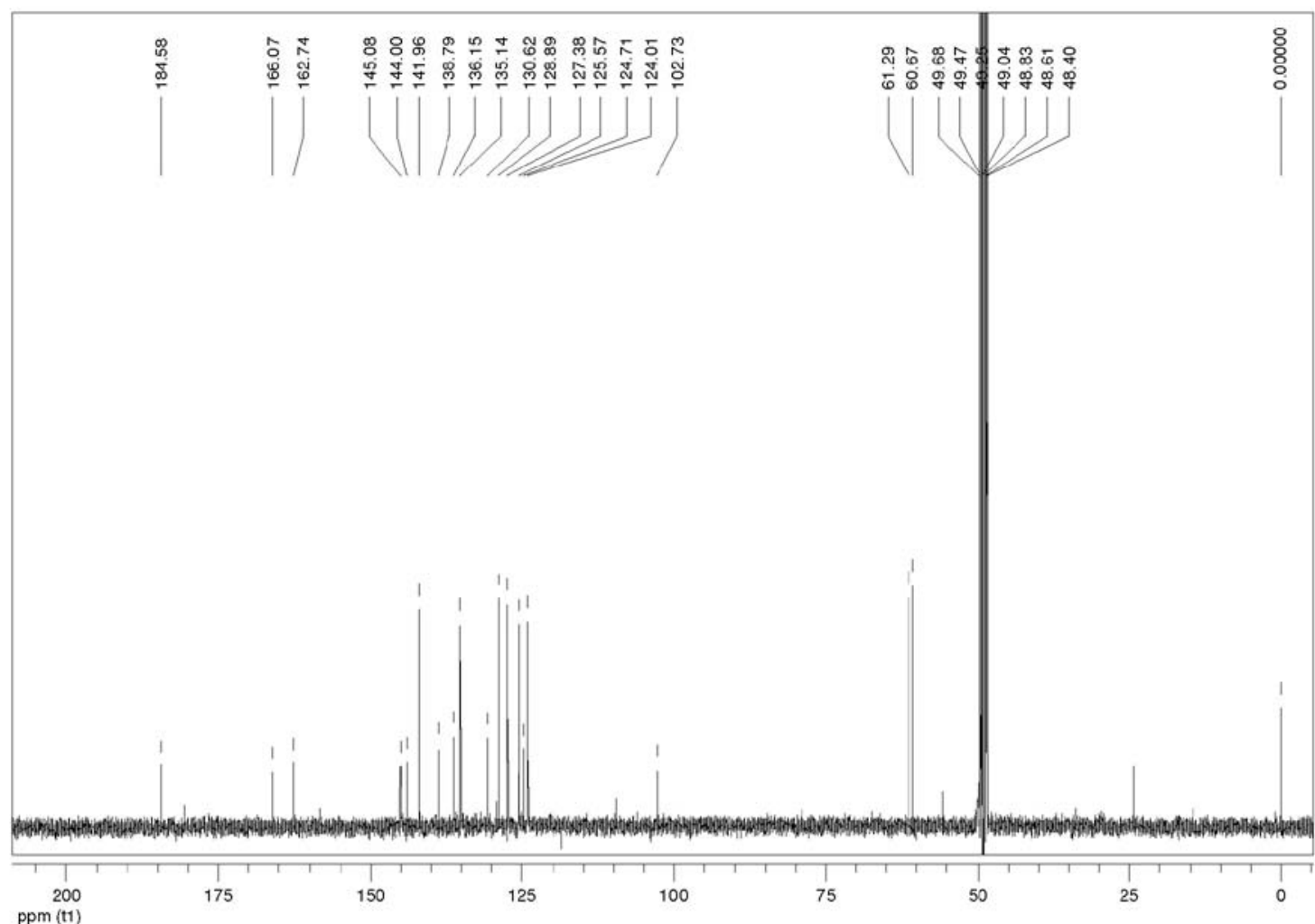

Figure S25. ${ }^{13} \mathrm{C}\left\{{ }^{1} \mathrm{H}\right\}$ NMR spectrum of compound 12 in $\mathrm{CD}_{3} \mathrm{OD}$ at $100 \mathrm{MHz}$.

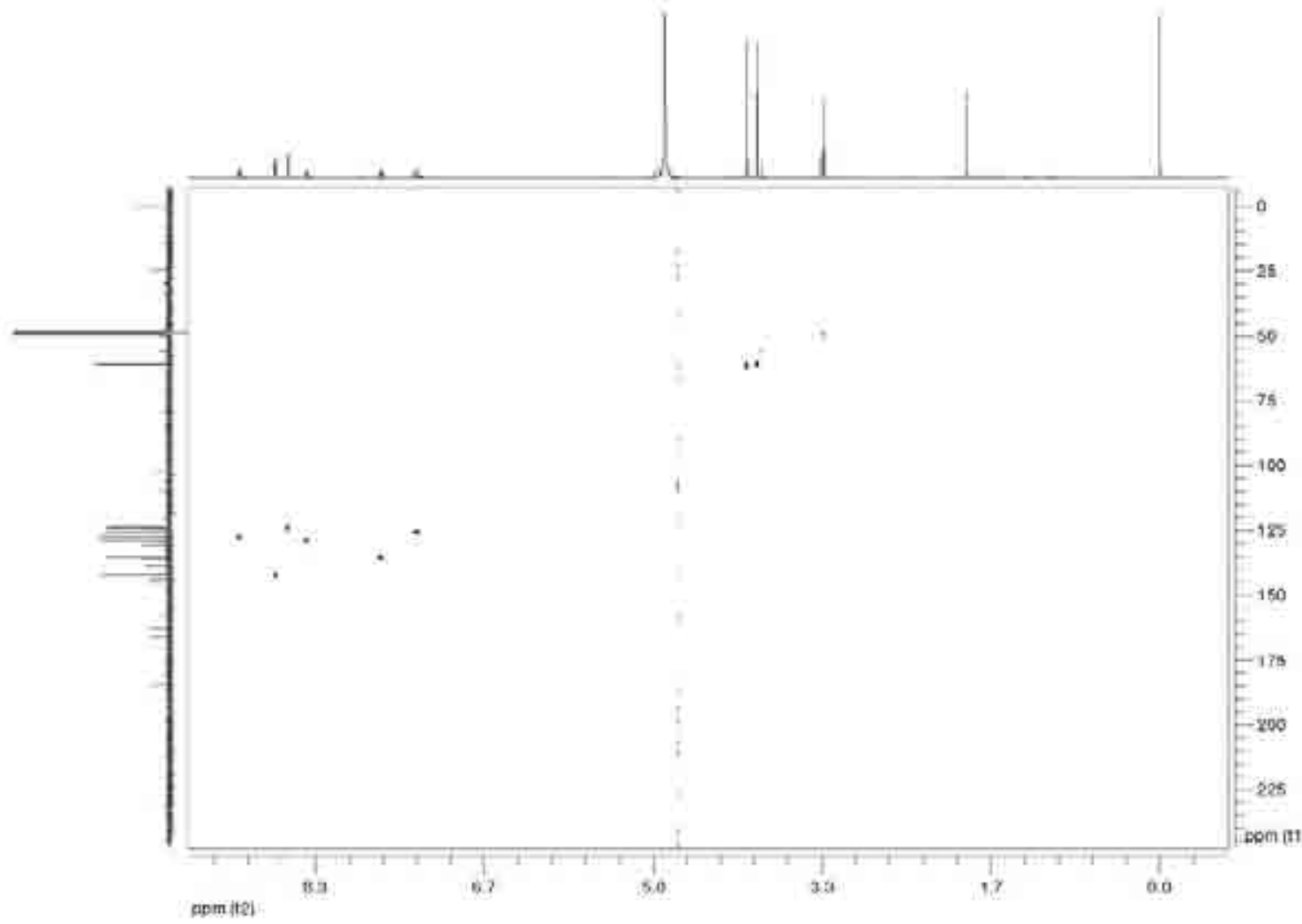

Figure S26. ${ }^{1} \mathrm{H}-{ }^{13} \mathrm{C}$ one-bond correlation map from HSQC NMR experiment of compound 12 in $\mathrm{CD}_{3} \mathrm{OD}$ at 400 and $100 \mathrm{MHz}$. 


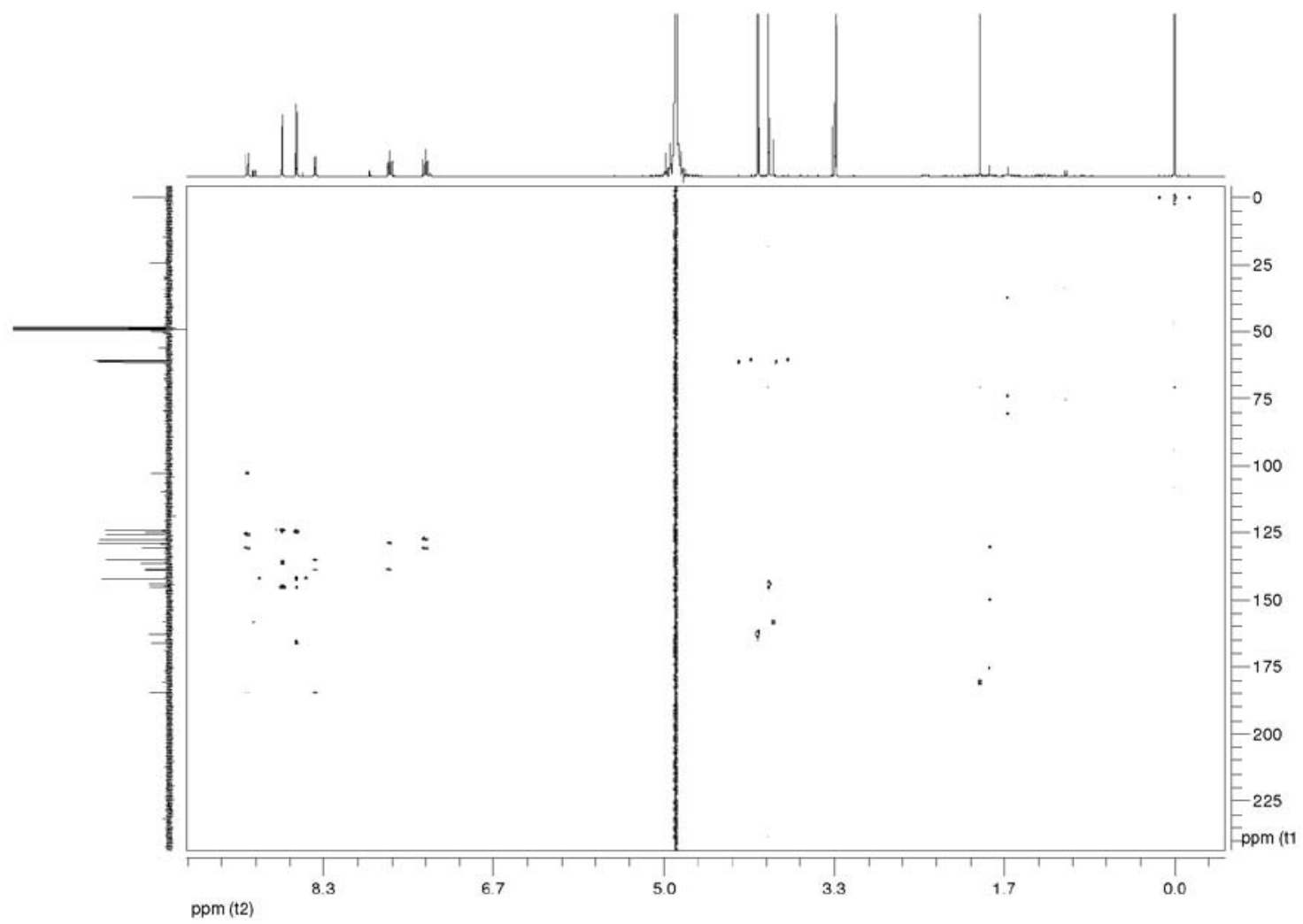

Figure S27. ${ }^{1} \mathrm{H}^{-13} \mathrm{C}$ long-range correlation map from $\mathrm{HMBC}$ NMR experiment of compound 12 in $\mathrm{CD}_{3} \mathrm{OD}$ at 400 and $100 \mathrm{MHz}$. 